\title{
Geophysical and magneto-structural study of the Maâdna structure (Talemzane, Algeria): Insights on its age and origin
}

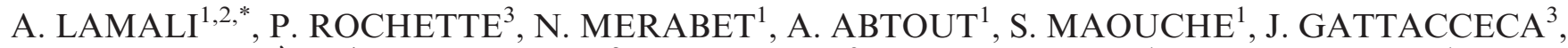 \\ L. FERRIÈRE ${ }^{4}$, M. HAMOUDI ${ }^{2}$, ASTER Team $^{3, a}$, E.H. MEZIANE ${ }^{1}$, and M. AYACHE ${ }^{1}$ \\ ${ }^{1}$ CRAAG, B.P. 63, Bouzaréah, 16340, Alger, Algeria \\ ${ }^{2}$ FSTGAT, USTHB. B.P. 32, El Alia, Alger, Algeria \\ ${ }^{3}$ CNRS, IRD, CEREGE UM34, Aix-Marseille Université, 13545, Aix en Provence, France \\ ${ }^{4}$ Natural History Museum, Burgring 7, A-1010, Vienna, Austria \\ "Corresponding author. e-mail: a.lamali@craag.dz
}

(Received 10 January 2016; revision accepted 05 July 2016)

\begin{abstract}
The Maâdna structure is located approximately $400 \mathrm{~km}$ south of Algiers $\left(33^{\circ} 19^{\prime} \mathrm{N}\right.$, $4^{\circ} 19^{\prime}$ E) and emplaced in Upper-Cretaceous to Eocene limestones. Although accepted as an impact crater on the basis of alleged observations of shock-diagnostic features such as planar deformation features (PDFs) in quartz grains, previous works were limited and further studies are desirable to ascertain the structure formation process and its age. For this purpose, the crater was investigated using a multidisciplinary approach including field observations, detailed cartography of the different geological and structural units, geophysical surveys, anisotropy of magnetic susceptibility, paleomagnetism, and petrography of the collected samples. We found that the magnetic and gravimetric profiles highlight a succession of positive and negative anomalies, ones that might indicate the occurrence of a causative material which is at least in part identical. Geophysical analysis and modeling suggest the presence of this material within the crater at a depth of about $100 \mathrm{~m}$ below the surface. Using soil magnetic susceptibility measurements, the shallowest magnetized zone in the central part of the crater is identified as a recently deposited material. Paleomagnetic and rock magnetic experiments combined with petrographic observations show that detrital hematite is the main magnetic carrier although often associated with magnetite. A primary magnetization is inferred from a stable remanence with both normal and reverse directions, carried by these two minerals. Although this is supposed to be a chemical remagnetization, its normal polarity nature is considered to be a Pliocene component, subsequent to the crater formation. The pole falls onto the Miocene-Pliocene part of the African Apparent Polar Wander Path (APWP). Consequently, we estimate the formation of the Maâdna crater to have occurred during the time period extending from the Late Miocene to the Early Pliocene. Unfortunately, our field and laboratory investigations do not allow us to confirm an impact origin for the crater as neither shatter cones, nor shocked minerals, were found. A dissolved diapir with inverted relief is suggested as an alternative to the impact hypothesis, which can still be considered as plausible. Only a drilling may provide a definite answer.
\end{abstract}

\section{INTRODUCTION}

Impact structures are generally first identified as anomalous circular or near-circular topographic features

${ }^{\mathrm{a}}$ M. Arnold, G. Aumaître, D.L. Bourlès, K. Keddadouche on satellite images. Typically, the inner anomalous area exhibits, depending on the level of erosion, a bedrock characterized by severe and localized deformations, uplifted rocks, and/or by the occurrence of a filling of impact breccias and/or impact melt rocks. In addition, a circular geophysical anomaly, typically observed in 
gravity or magnetic maps, may be associated with a surface or subsurface structural feature. Therefore, a set of geophysical criteria were defined, using various geophysical techniques, that are characteristic of impact structures (e.g., Pilkington and Grieve 1992; Grieve and Pilkington 1996).

The Sahara, the largest hot desert in the world, has 11 impact structures currently considered as "confirmed" according to Reimold and Koeberl (2014). Four of these 11 are located in Algeria, while Chad, Mauritania, and Libya bear two impact structures each, and Egypt one (Earth Impact Database, 2013). Despite the scientific and potential economic interest of these structures, most of the current knowledge on the Algerian impact structures is inferred from exploratory works achieved in the late 1970s (see Lambert et al. 1980, 1981). More recent investigations (McHone and Greeley 1987; Koeberl 1994; Belhaï et al. 2006) essentially deal with field mapping, confirming previous results (Karpoff 1953; Lambert et al. 1980, 1981). Perhaps the most controversial of these structures is the Maâdna structure in Algeria (Fig. 1), which has been previously named Talemzane in the literature and formed in Upper-Cretaceous to Eocene limestones. Although previously accepted as an impact crater on the basis of alleged observations of shock-diagnostic features such as planar deformation features (PDFs) in quartz grains, its origin still remains poorly constrained.

However, establishing the impact origin of a given suspected structure requires the discovery and characterization of unique impact-induced features. Currently, the only accepted impact features are macroscopic shatter cones, microscopic evidences of shock metamorphism, and/or a distinctive extraterrestrial geochemical signature (i.e., contamination from the impactor) in the rocks associated with the structure (see e.g., French 1998; French and Koeberl 2010; and references therein). If we assume the relevance of these criteria, previous works were limited and failed to fully support an impact origin at Maâdna structure. Moreover, the precise age of the crater is not yet known. Consequently, this study aimed at recognizing and quantifying the local and/or regional deformations induced by the impact and postimpact processes. This is done with the acquisition of new magneto-structural and geophysical data to better constrain the structure and its age.

Although a well-defined circular geophysical anomaly can suggest the presence of a possible impact structure, the discovery of such anomalies should be followed by the finding, via drillings and/or sample collection at the surface, of distinctive shock metamorphism effects in minerals, in ideal case supported by extraterrestrial chemical/isotopic signatures in the associated rocks (e.g., Corner et al. 1997; Hart et al. 1997; Koeberl 1997). A large number of confirmed impact structures on Earth were first identified as geophysical anomalies and their impact origin only established later through detailed geological and petrological investigations (e.g., Pilkington and Grieve 1992). For this purpose, the Maâdna crater-like structure, located approximately $400 \mathrm{~km}$ south of Algiers $\left(33^{\circ} 19^{\prime} \mathrm{N}, \quad 4^{\circ} 19^{\prime} \mathrm{E}\right)$, was investigated using a multidisciplinary approach, based on detailed mapping of the different geological and structural units (see Lamali et al. 2009) combined with the acquisition of a large number of geophysical measurements. The geomorphological and geological investigations are based on detailed topographic, structural, and stratigraphic studies. Ground magnetic and magnetic susceptibility surveys were performed along radial traverses profiles. A number of rocks (including breccias) and soils were sampled for magnetic properties, paleomagnetic, magnetofabric, and petrographic investigations.

In the first part of this paper, the local geological setting of the structure is reviewed and updated with data collected during our fieldwork. Second, the petrography of the main rock types is presented for the identification of shock-induced changes in the different lithologies occurring at Maâdna. The collected geophysical data are analyzed and interpreted in the last part. As a complement to our geophysical investigations, we have included newly processed gravity data that were previously collected at the structure by another collaborative research team from the CRAAG and USTHB University, Alger (data reported in Sahoui 2009). While the petrophysical and rock magnetic data complement our petrographic study, they are also used for the identification of remanence carriers and/or shock effects (Hargraves and Perkins 1969; Pohl and Soffel 1971; Halls 1975; Pesonen et al. 1992; Gattacceca et al. 2007; Louzada et al. 2008). Consequently, the impact cratering process, age, and origin of the Maâdna structure is discussed using a hypothetical magnetostructural model based on magnetofabric, paleomagnetic, and geophysical surveys data.

\section{GEOLOGICAL SETTING}

\section{Previous Works}

The Algerian impact structures are all developed on the Sahara Platform and in sedimentary rocks initially lying subhorizontally. The Maâdna (Talemzane, Algeria) crater is located approximately $400 \mathrm{~km}$ south of Algiers, at $33^{\circ} 19^{\prime} \mathrm{N}, 4^{\circ} 19^{\prime} \mathrm{E}$ (Fig. 1). It is a wellpreserved bowl-shaped crater with a rim to rim diameter of about $1.7 \mathrm{~km}$. 


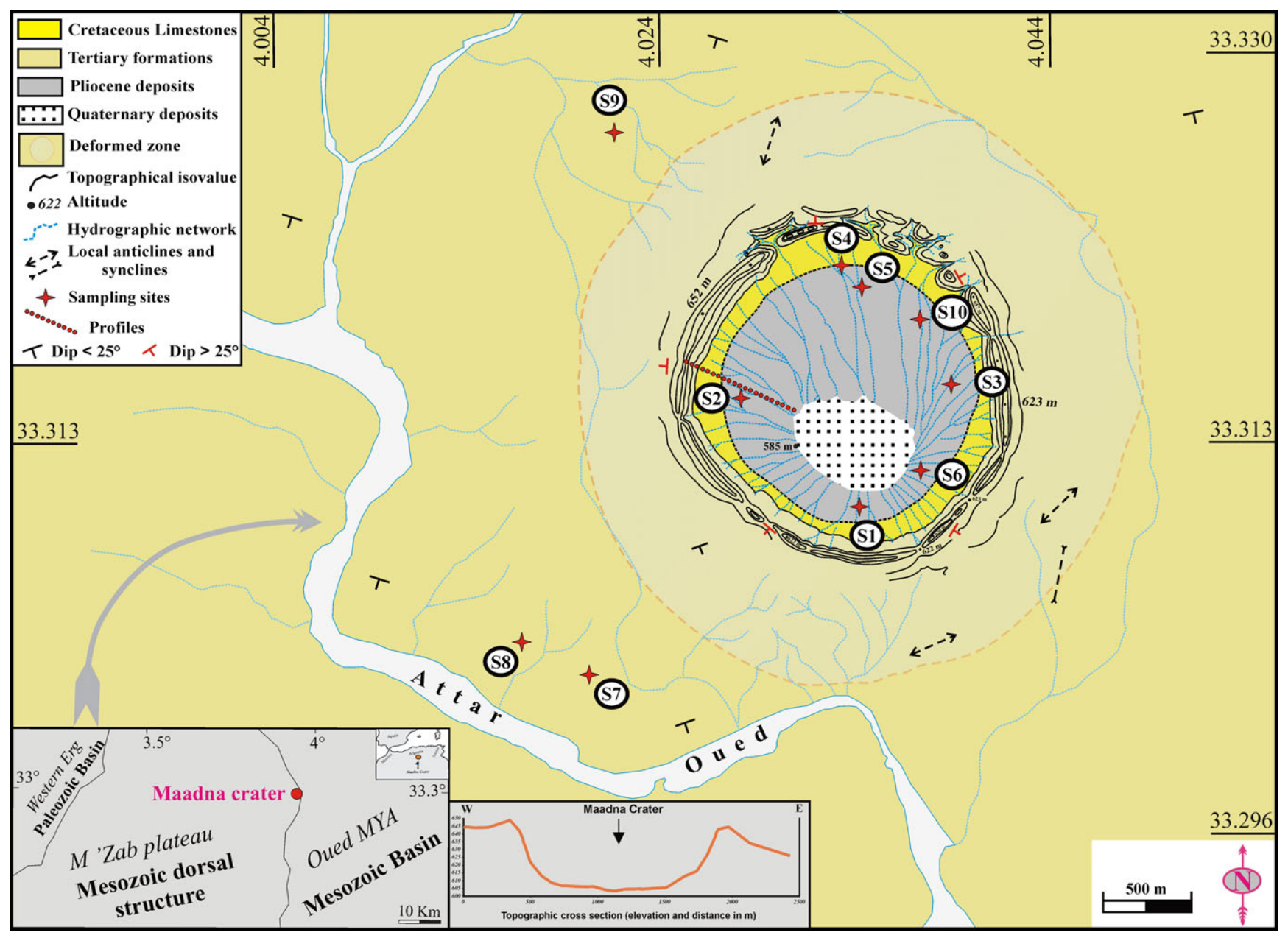

Fig. 1. Topographic and geological sketch map of the Maâdna structure (after Karpoff [1953] and our own observations), and location of the paleomagnetic sampling sites including location map of the major geological provinces (after McHone and Greeley 1987) and EW vertical profile from SRTM elevation data sets.

The Maâdna structure lies to the north of the M'Zab plateau which characterizes the Mesozoic dome structure of the Algerian Sahara platform (Fig. 1). The geology of the M'Zab plateau is well known, thanks to the discovery of a giant gas field at Hassi R'Mel (see e.g., Magloire 1970). The M'Zab plateau is a long North-South monocline that encounters to the North an East-West syncline of Cretaceous-Eocene strata, parallel to the Atlas folds, and is buried to the South beneath the extremely thick ( $\sim 550$ to $650 \mathrm{~m}$ ) continental Tertiary formations (Karpoff 1953; Magloire 1970; McHone and Greeley 1987; Askri et al. 1995).

The first field trip to the Maâdna structure for which we have written traces took place in 1951. The structure was investigated the following year by plane (Karpoff 1953). This investigation marked the pioneering work that allowed the preliminary sketch of Maâdna structure to be established using the interpretation of aeromagnetic data. At that time an impact origin was proposed based on the morphological and structural observations. Karpoff (1953) suggested the name Talemzane rather than the original Arabic name of Daeit El Maâdna; Talemzane is a small fortified water cistern located about $9 \mathrm{~km} \mathrm{NW}$ from the crater. The proposed name of Talemzane was until very recently still used in the literature (e.g., Lambert et al. 1980; Koeberl 1994; Reimold and Koeberl 2014). However, in recent studies conducted by Algerian researchers, it was suggested to rename it "Maâdna," a more geographically appropriate name for the area where the crater is located (Belhaï et al., 2006). We support the proposed name of Maâdna given that the local name "Daiet" means "depression."

Further geological investigations by Lambert et al. (1980) have yielded to a schematic cross section of the structure to be established, highlighting the occurrence of different brecciated levels and of strongly fractured limestone beds. According to their cross section, breccia 
veins occur at the crater wall and detrital or reworked monomict breccia is found at the crater floor, near the rim. Furthermore, the limestone beds are locally upturned or overturned at the rim, with large blocks of ejected limestone scattered along the outer rim. Lambert et al. (1980) report on limited shock metamorphism evidences in the form of "planar elements" (i.e., it is not clear if they are planar fracture (PFs) or PDFs in three or four quartz clasts. These "planar elements" are decorated and of one or two different orientations per grain.

During the 1980s, the morphology of the Maâdna structure was investigated again using data from the Space Shuttle (SIR-A) orbital imaging radar (McHone and Greeley 1987). More recent investigations led to significant mapping reports (Belhaï et al. 2006; Sahoui 2009).

Using structural observations, Karpoff (1953) proposed a Pliocene age for the crater. Similarly, Lambert et al. (1980) proposed an age of about $3 \mathrm{Ma}$, based on the intensity of the erosion affecting the Maâdna structure.

\section{Field Work}

Our interdisciplinary team conducted a 9-day field mission to the Maâdna structure, dedicated to geological mapping, geophysical measurements and sampling for paleomagnetic and petrography studies were conducted in early May 2008. Core samples were collected inside and outside of the crater, from the autochthonous limestone as well as from the breccia outcrops. The field work included search of impact melt through evidence of magnetic material, using a magnetic gradiometer (type Foerster, FEREX 4.032). In addition, in situ magnetic extraction of sand and gravel was performed. All these investigations are described in more detail in the corresponding sections.

The data collection during our geological field study was completed by information derived from aerial photographs. As a result, a new detailed geological map of the Maâdna structure was drawn (Fig. 1). Additional information has been added to this map to emphasize the deformed zone around the crater, the major distribution of the disturbed hydrographic network, and the surrounding tectonic structures as small anticlines and synclines. Topography and specific sampling site locations together with their assigned numbers, are also displayed. We also report on some measurements of the outward dipping of the limestone beds from the crater. The central zone of the crater is represented with its Quaternary deposits (Fig. 1). Furthermore, our geological map was refined right around the Maâdna crater to provide better identification of the structural features and rock units. The resulting map (Fig. 2a) reveals that the limestone breccia can be seen in outcrops close to the crater walls, grading inward to the central part. On the other hand, the intensely fractured autochthonous limestone crops out at the crater rim walls. An unusual limestone breccia, interpreted as an ejecta unit/facies by Lambert et al. (1980), was documented in some restricted area located inside and outside the crater. As visible in Fig. 2a, we report on details of the Pliocene and Quaternary alluvial deposits located within the crater. A set of dip measurements and the position of mapped anticlines and synclines located around the deformed area are also indicated.

Limestone beds host numerous breccia veins in fractures, sometimes oriented parallel or perpendicular to the stratification (Fig. 3a). The Pliocene deposits are composed of conglomerates, breccias, and alluvial sand deposits with clay material filling cavities (Fig. 3b). The breccia is cemented with calcite, formed probably long after the formation of the crater. The autochthonous Cretaceous limestone with flint inclusions is highly fractured (Fig. 3c). In some places the lower part of the inner and outer walls exhibits unusual structural features such as highly fractured and relatively stable zones, without any obvious preferential orientation (Figs. 3c and 3d). A black varnish often observed on weathered limestone may have been misleadingly interpreted by previous authors as melted material (Fig. 3e). Compared to breccia veins occurring in Cretaceous limestone, the Pliocene conglomeratebreccias exhibit a distinct texture and geometry (Fig. 3). Our field observations are generally consistent with previous studies (Karpoff 1953; Lambert et al. 1980; Belhaï et al. 2006). However, some type of outcrops (e.g., Pliocene breccias, conglomerate, weathered limestones) described by former authors inside the crater, were also found outside the crater.

A detailed lithologic log of the M'Zab plateau geological zone is reported in Fig. $2 b$ based on information given by Askri et al. (1995). Although Lower Cretaceous deposits do not outcrop in the Maâdna region, drillings have shown that $\sim 1000 \mathrm{~m}$ thick claystone and sandstone units occur (Askri et al. 1995). Above the Cretaceous deposits, Tertiary marine and lacustrine sediments cover the region. About $200 \mathrm{~km} \mathrm{SW}$ of the crater, up to $250 \mathrm{~m}$ of Cenomanian gypsum-bearing marls, shales, and fine-grained sandstones crop out in fluvial terrains. In the vicinity of Maâdna crater, Turonian dolomitic limestones facies dominate the northern part of the M'Zab plateau. They are covered to the North and East by younger Senonian (Coniacian to Maastrichtian, 85-65 Ma) deposits, up to $120 \mathrm{~m}$ in thickness. On the other hand, late cretaceous sandy limestones and dolomites overlay ferruginous 


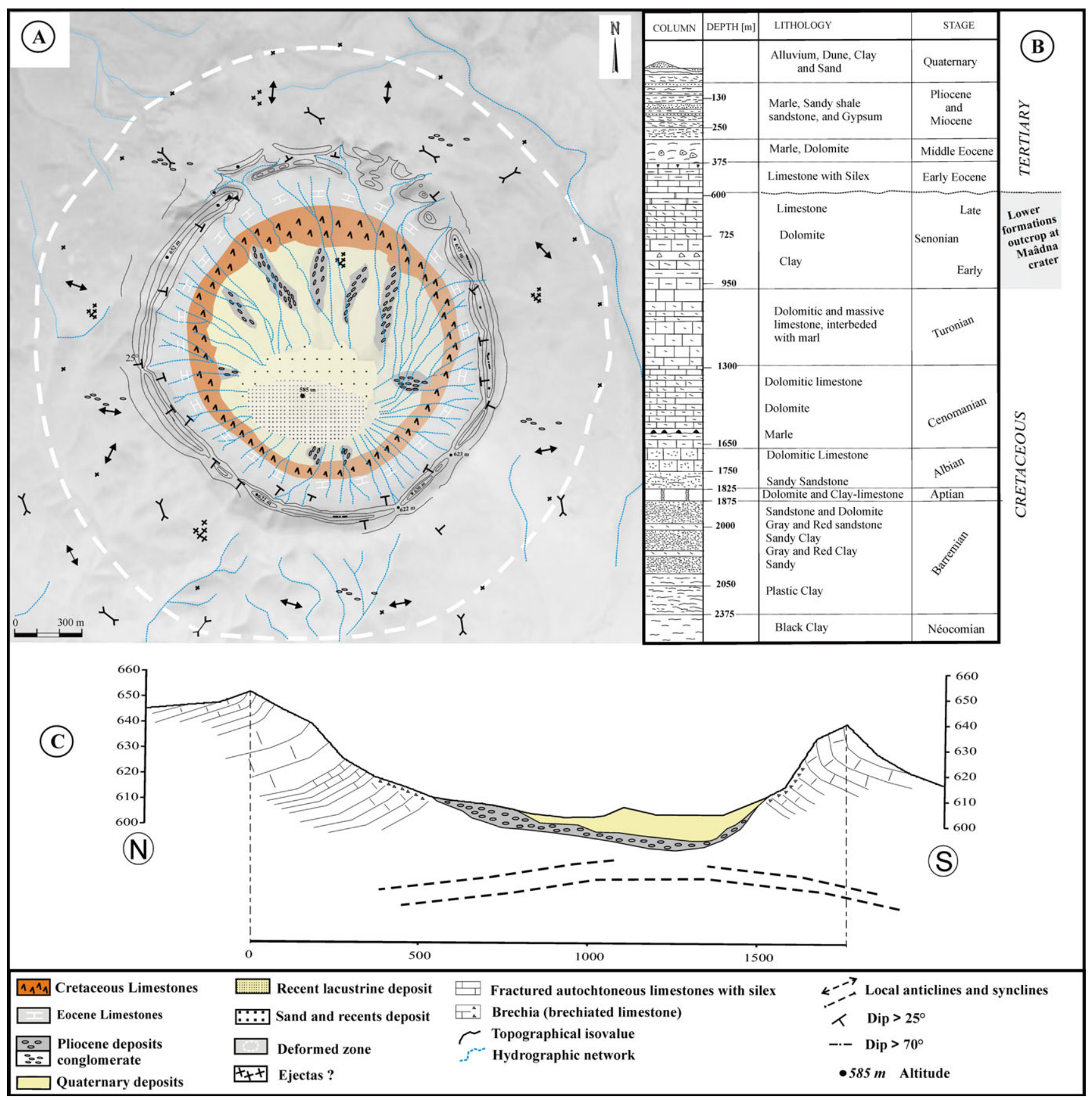

Fig. 2. a) Detailed geological map of the Maâdna structure. b) Synthetic stratigraphic sequence of the targeted zone (after Askri et al. 1995). c) Structural N-S cross section of the crater correlated with topographic SRTM data.

marls containing thin gypsum veins. Paleogene continental formations are mainly composed of limestone with flint inclusions from the Eocene. Finally, the Neogene and Quaternary deposits are composed of marl, sandy shale, sandstone, gypsum, and alluvium.

Morphologically, the shape of the Maâdna crater is nearly elliptical (see Figs. 1 and 2a). The morphology of the crater was investigated using the Global Mapper software and data from the Shuttle Radar Topography Mission (SRTM). Two profiles were obtained showing that the E-W rim dimension is about $1600 \mathrm{~m}$, whereas the N-S rim dimension is about $1750 \mathrm{~m}$, which gives an eccentricity of about 1.093. This N-S topographic profile was used to define the range of elevations in our 


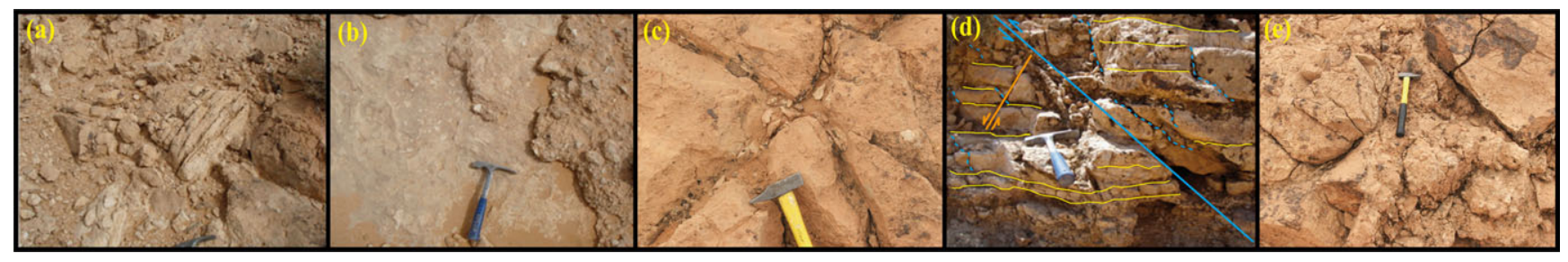

Fig. 3. Field photographs: a) upturned strata; b) breccias veins; c) fracture pattern; d) distinctive faulted limestone layers; e) presumed ejecta blocks.

newly compiled N-S cross section (Fig. 2c). This N-S section highlights the upturned nature of the autochthonous limestone strata from the upper part of the principal crater wall. As shown on this figure, the quaquaversal dip of the strata decreases rapidly below $\sim 80^{\circ}$ on the top, to $\sim 20^{\circ}$ at the base of the foot wall of the crater. In addition, we have delimited within the deformed zone the occurrence of what was previously suspected to be the remnants of an ejecta blanket, in the form of large blocks as well as some conglomerates (Fig. 3). However, the weathering and erosion of the outcrops renders geological interpretation in the near surface disturbed layers difficult.

\section{COSMOGENIC RADIONUCLIDE DATING}

In terms of relative dating of the excavation of the structure, we confirm a pre-Pliocene age (i.e., at least $3 \mathrm{Ma}$ ), based on the clear Pliocene infill of the crater. Also, besides the semidesertic climate and hardness of the limestones, a significant incision of the northern crater rim occurred (Fig. 1) and the surrounding hydrographic network seems to postdate the structure (e.g., arcuate stream westward from the crater). Two calcite-bearing samples were collected in the crater rim, about $20 \mathrm{~m}$ below the external top surface. Samples were crushed, sieved, and $\mathrm{Cl}$ was chemically extracted under $\mathrm{AgCl}$. The $\mathrm{Cl}$ and ${ }^{36} \mathrm{Cl}$ concentrations were then determined by isotope dilution accelerator mass spectrometry from the measured ${ }^{35} \mathrm{Cl} /{ }^{37} \mathrm{Cl}$ and ${ }^{36} \mathrm{Cl} /{ }^{35} \mathrm{Cl}$ ratio performed at the French national Accelerator Mass Spectrometry facility ASTER (CEREGE, Aix-enProvence). The ${ }^{36} \mathrm{Cl}$ and $\mathrm{Cl}$ concentrations were normalized to a ${ }^{36} \mathrm{Cl}$ standard prepared by $\mathrm{K}$. Nishiizumi: KNSTD1600 with a given ${ }^{36} \mathrm{Cl} /{ }^{35} \mathrm{Cl}$ value of $(2.11 \pm 0.06) \times 10^{-12}$ (Fifield et al. 1990; Sharma et al. 1990). The decay constant of $2.303 \pm 0.01610^{-6} \mathrm{yr}^{-1}$ used corresponds to a ${ }^{36} \mathrm{Cl}$ half-life $\left(T_{1 / 2}\right)$ of $3.014 \times 10^{5} \mathrm{yr}$. Analytical uncertainties include counting statistics, machine stability, and blank correction. The sample concentrations were of 2.95 and $3.6710^{6}$ atoms ${ }^{36} \mathrm{Cl} \mathrm{g}^{-1}$, respectively. Since the age of the structure is $>0.5 \mathrm{Ma}$, the two samples can be interpreted as being at steady state in term of cosmogenic nuclide production and the ${ }^{36} \mathrm{Cl}$ concentration can then be quantitatively interpreted as a denudation rate (Bierman and Steig 1996; Schimmelpfennig et al. 2009).

\section{PETROGRAPHY}

The petrography of the main rock types occurring at the Maâdna structure was already reported by Lambert et al. (1980). We report here a brief description of the main petrographic features, with a focus on the opaque minerals (which are relevant for the rest of our study) and we also report on our search of evidence of shock metamorphism (such as PDFs in quartz grains).

At least three thin sections were prepared from a set of drill cores at each paleomagnetic sampling site (Fig. 1), thus covering most rock types of the studied area. In addition, four hand-size block samples were investigated. Two of them were collected inside the crater, close to sites 1 and 4 (see Fig. 1). The two other samples were collected outside the crater, near the site 7. These block samples have similar compositions, exhibiting the typical features of the matrix-supported limestone breccia. Overall, about 33 oriented thin sections were prepared from selected samples in order to characterize their mineralogy and their grain-scale microstructure. Microscopic observations were done using a petrographic microscope using both transmitted and reflected light.

Our microscopic observations (Fig. 4) reveal a variety of different limestone lithologies, which also occur in the population of lithic clasts in the breccia samples. A small proportion of single calcite and quartz grains/crystals were also observed. The matrix of the breccia samples consists of mottled micrite and is rich in fossils and fossil fragments (Fig. 4a). It is coherent and mainly composed of fine-grained calcium carbonate with a small proportion of barite, apatite, and opaque minerals (mainly $\mathrm{Fe}-\mathrm{Ti}$ oxides). Some samples of Cretaceous limestone breccias contain typical fossil algae (especially calcareous algae), with sparry calcite and fine sediment filling the marginal pores (Figs. $4 \mathrm{~b}$ 


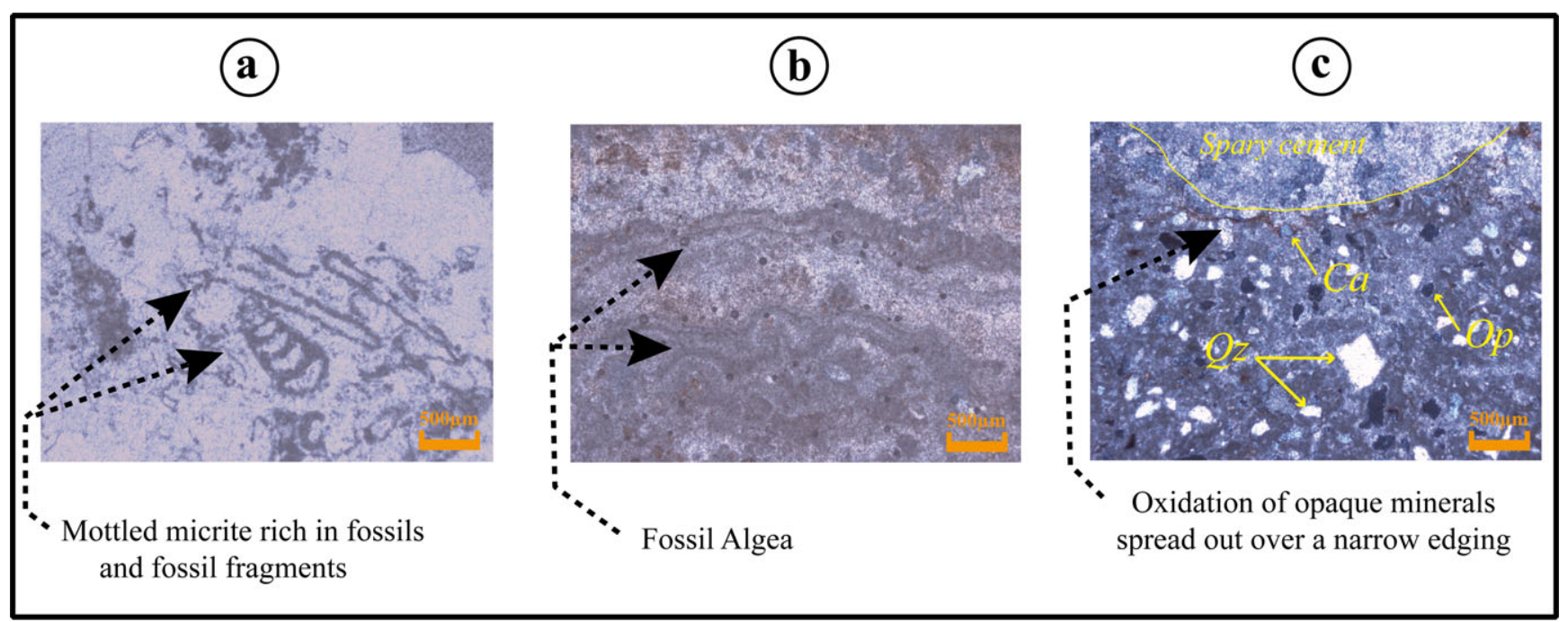

Fig. 4. Microscopic observations of thin sections from studied Maâdna rocks in transmitted light with crossed nicols. (a) Example of the mottled micrite rich in fossils and fossil fragments. (b) Observed fossil algae. (c) Oxidation of opaque minerals. Qz: quartz, Op: opaque, Ca: calcite.

and $4 \mathrm{c}$ ). We have observed (in reflected light) diffuse rinds and veinlets of hematite (e.g., Fig. 4c). This may suggest an oxidation of primary oxide grains (such as Ti-magnetite). Our analysis of 33 oriented thin sections of limestone and breccia samples did not reveal any evidence of a specific preferred orientation of the minerals.

Definite and unequivocal petrographic evidence of shock metamorphism is very limited and questionable in the case of the Maâdna structure. So far, only Lambert et al. (1980) have reported on the finding of what they interpreted to be shocked quartz grains. They report on the occurrence of "three or four quartz clasts" with "definite planar elements" decorated by fluid inclusions. Their "planar elements" occur only in one or two different orientations per grain. Although not further specified in Lambert et al. (1980), it seems that they have determined the orientation of these "planar elements" since crystallographic orientations are reported on the two microphotographs (i.e., their figure 12) that are visible in their manuscript. The described and illustrated features are questionable and would need to be properly confirmed to be accepted as definite evidence of shock metamorphism. For this reason, all our thin sections were carefully investigated for the possible occurrence of shocked quartz grains. Unfortunately, no shocked quartz grains were observed in the investigated Maâdna samples. The fact that we were not able to find shocked quartz grains or to confirm the observations from Lambert et al. (1980) cannot be considered to definitely reject an impact origin of the Maâdna crater.

\section{GEOPHYSICS}

\section{Ground Magnetic Data}

The detailed characteristics of magnetic anomalies associated with impact craters are generally more complex than those of other geophysical signatures due to the large variations in magnetic properties of rocks and in the direction of the magnetization (Pilkington and Grieve 1992). The purpose of our magnetic survey is to determine the magnetic signature of the Maâdna crater and to delineate subsurface structures.

The ground survey of the total magnetic field intensity was carried out using two proton precession field-portable magnetometers (Overhauser type, GEM System) with single-sensor. The Earth magnetic field varies with time mostly due to magnetic storms and diurnal variations. Therefore, the first magnetometer was used as a base station in order to correct all these temporal changes. The second magnetometer was used for measuring the total magnetic field intensity at different locations in the study area. In the central part of the crater, measurements were made along traverses resulting in a cell size of about $20 \times 20 \mathrm{~m}$. From inside to outside the crater, the perpendicular tie-lines at 150 $200 \mathrm{~m}$ intervals were used while the sampling distance along the profiles was about $50 \mathrm{~m}$ (Figs. 5A-1 and 5A2).

After correction for diurnal variations and subtraction of an appropriate geomagnetic reference field (IGRF) for the date of the survey, the total-field anomaly data were gridded through a minimum 


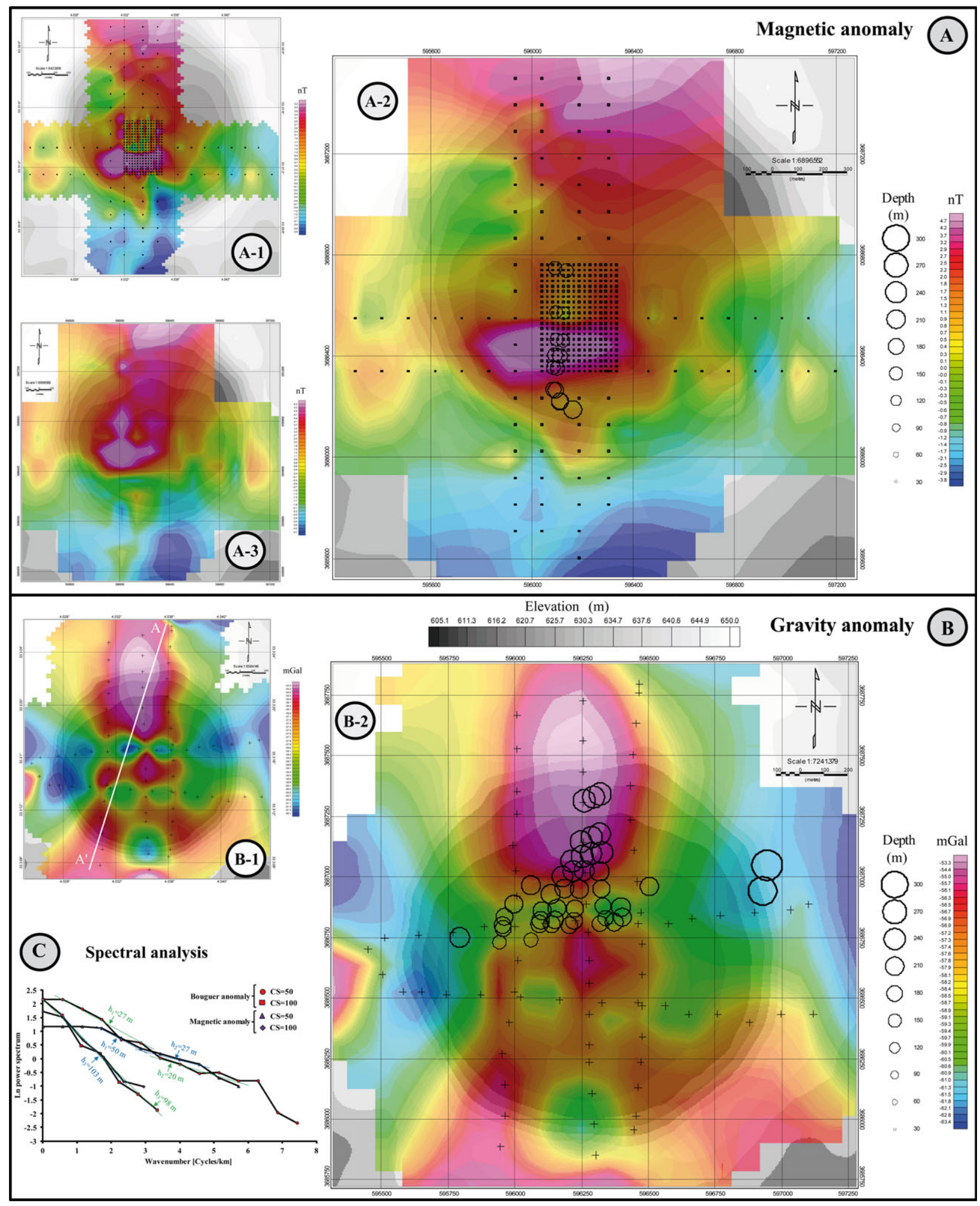

Fig. 5. Compilation of magnetic and gravity anomaly maps. A-1) Total intensity magnetic anomaly map corrected from diurnal drift. A-2) Filtered magnetic anomaly map including depth estimation using Euler deconvolution. A-3) Reduced-to-pole magnetic anomaly map. B-1) Bouguer anomaly map. B-2) Filtered Bouguer anomaly map including depth estimation using Euler deconvolution; dots correspond to measurement sites. The gray shaded reliefs on the maps represent a topographic composite grid of the crater. C) Spectral analysis: Calculated radially averaged power spectrum of the filtered magnetic and gravity data, using 50 and $100 \mathrm{~m}$ as optimal values for the cell size (CS). 
curvature method using Oasis Montaj, a geophysical data processing software from Geosoft ( $\mathrm{V}$ 8.0.1). The resulting 2-D map of the total magnetic field anomalies is shown in Fig. 5A-1. Considering our irregular grid against the distances between station locations, we have performed a filtered grid window by specifying a suitable grid cell size value. In our case, the best fitting of the data sample interval is found for a grid cell size value of about $100 \mathrm{~m}$. This filtering allowed better characterization of the suspected anomalies (Fig. 5A-2). The overall variability of the magnetic field is low (about $8 \mathrm{nT}$ ), with a general decrease from $\mathrm{N}$ to $\mathrm{S}$. As seen in this Fig. 5A-2 and furthermore in the magnetic anomaly map reduced to the pole (Fig. 5A-3), a rather sharp positive anomaly of about $5 \mathrm{nT}$ is found in the crater depression. This anomaly is, however, offcentered to the SW, and lies more or less above the topographic center of the depression.

With the aim of inferring the exact location of the causative sources of the observed anomalies, we applied Euler deconvolution within Geosoft software using E3XYEULER GX subroutine. Euler deconvolution requires only a little prior knowledge about the magnetic source geometry beyond information about the magnetization vector (Thompson 1982; Reid et al. 1990). On the other hand, the 3-D Euler solution shows more useful results where we can delineate almost accurately the zones of magnetic contact. These contacts are estimated to be located at different depths ranging from 50 to $300 \mathrm{~m}$, based on the solutions that were given by the 3-D Euler solution maps (Fig. 5A-2). The deepest causatives sources found around the central depression of the Maâdna structure give mainly an Euler solution of $100 \mathrm{~m}$.

The magnetic sources from Euler deconvolution correspond approximately to the top of the magnetic sources which reflect the magnetic body beneath the thick sediment that fills the Maâdna depression. Additionally, more details about the shallower anomalies, such as estimating the depth to the bottom of the magnetized bodies, should be then revealed by the spectral analysis method. The latter is based on the relationship between the spectrum of magnetic anomalies and the depth of the magnetic source using Fourier transformation of gridded data into wave or frequency domain. However, using the Magmap extension of Oasis Montaj (FFT2RSPC GX), the cutoff wavelengths and information about the contribution of the short and long wavelengths in the spectrum can be obtained from the calculated radially averaged power spectrum of the data using $50 \mathrm{~m}$ and $100 \mathrm{~m}$ as optimal values for the cell size (Fig. 5C).

The result (Fig. 5C) shows that the depth to the top of the deepest magnetic source around the central part of the Maâdna depression is about $100 \mathrm{~m}$ with two shallower ones around 20-30 m. We performed direct calculation (Henderson and Zietz 1948; Peters 1949; Sailhac 1999) to confirm these proportional values. This suggests a concentration of more magnetic material deposited in the depression and thus posterior to the formation of the Maâdna depression. The shallower anomalies may correspond to concentrated magnetic particles characterizing the Quaternary deposits. Estimates of magnetization contrasts will be discussed below (see the Sampling section).

\section{Gravity Data}

To complete our geophysical investigations, we have reprocessed the gravity data previously collected on this structure (Sahoui 2009). The survey consists of the intersection of five profiles (Fig. 5B-1 and 5B-2) and covers the entire crater area. The distance between gravity stations is about $50 \mathrm{~m}$. The gravity measurements were acquired by a Scintrex CG3 meter. Gravity data accuracy was controlled by making repeated readings on selected stations. The elevations were determined using a topographic survey for measured gravity stations which we correlated here with our DEM using SRTM data.

Gravity data were reduced to Bouguer anomaly using standard gravity methods and corrections (including the instrument height reductions, Earth tides, instrument drift, latitude, free-air, Bouguer correction computed with a density of $2.5 \mathrm{~g} \mathrm{~cm}^{-3}$, and terrain correction removing the effect of topography). The data were gridded through a minimum curvature method and the resulting 2-D map is shown in Fig. 5B-1 using Oasis Montaj software. To better characterize the suspected anomalies, a filtering procedure, similar to magnetic data, was applied to the gravity data. A grid cell size value of about $100 \mathrm{~m}$ produces the best fitting of the data sample interval (Fig. 5B-2). Maximum range of Bouguer anomaly variation is about $10 \mathrm{mGal}$. Overall the $\mathrm{N}$ and $\mathrm{S}$ rim show positive anomalies, and $\mathrm{E}$ and $\mathrm{W}$ negative anomalies, while a sharp positive anomaly appears at the crater center. Still the major signal corresponds to the gravity high on the $\mathrm{N}$ rim, while the central positive anomaly is defined by a very limited number of measurements.

In order to locate the geological structures responsible for the observed anomalies, we have used the E3XYEULER GX subroutine computing Euler depth deconvolution (e.g., Thompson 1982) to obtain solutions depths from given measured locations in the built database. Independently from density contrasts, this method allows the location of the anomaly sources (Blakely 1996). Throughout the Maâdna structure, this 
method provides source depth estimates ranging from 50 to $300 \mathrm{~m}$ (Fig. 5B-2). The most significant depth values could be associated with the deepest sources of the positive anomaly that coincides with the northern rim, including those of the $\mathrm{E}$ and $\mathrm{W}$ negative anomalies.

More precise shallow anomaly depths are computed using the FFT2RSPC GX to calculate the radially averaged power spectrum of an FFT2 Transform image of the obtained filtered gravity grid using $50 \mathrm{~m}$ and $100 \mathrm{~m}$ as optimal values for the cell size (Fig. 5C). Three main solutions have been found (Fig. 5C). The deeper one is located at more than $100 \mathrm{~m}$, while the shallower ones are located at $30 \mathrm{~m}$ to $50 \mathrm{~m}$. As revealed above by the magnetic signatures, these particular correlating bodies are likely related to the postemplacement history of the Maâdna depression.

\section{Soil Magnetic Susceptibility Survey}

The magnetic signature associated with impact craters is often characterized by a magnetic low due to a reduction in magnetic susceptibility (Pilkington and Grieve 1992), although central magnetic highs are also encountered (Quesnel et al. 2013). In order to better constrain a realistic model of the Maâdna magnetic anomaly, soil magnetic susceptibility (MS) investigations were carried out along the same radial traverse profiles as those of our ground magnetic survey (Fig. 6). We have used the Bartington MS2D probe system which we calibrated using a SM30 (ZH Inst.) magnetic susceptibility meter.

After the same filtering procedure as in magnetic or gravity data (Fig. 6), we found a pronounced MS anomaly in the measured soil profiles. The anomaly is limited to the topographic low with sediment accumulation in the central zone of the crater. Despite the visual homogeneity of the soil in the depression, the MS anomaly is roughly superimposed over the shallower magnetic anomaly (Fig. 6). This observation confirms that the recent sediments accumulated in the depot center are more magnetic than the surrounding formation, thus accounting for the magnetic field anomaly.

\section{ROCK MAGNETIC AND PALEOMAGNETIC STUDY}

\section{Sampling}

In addition to the hand-collected block samples, a rock magnetic and paleomagnetic sampling of the Maâdna structure was conducted over 10 sites inside and outside the crater (Fig. 1). The samples were collected using a portable gasoline-powered drill unit and were oriented using magnetic compass (and also, whenever possible, using solar compass). The present geomagnetic field declination was calculated using the IGRF. At each site, 10 to 20 cores were collected along a profile from the top of the rim to the foot wall (Fig. 1). For comparison, three sites were sampled in limestones outside of the structure. A total of 148 cores were sampled from 10 sites (Fig. 1). Sites S1, S2, S3, S4, S7, and S9 (Fig. 1) were sampled in the ConiacianMaastrichtian limestones, while sites S5, S6, S8, and S10 were sampled in the Pliocene conglomerate or breccia deposits.

\section{Rock Magnetism}

All magnetic analyses were performed at CEREGE magnetism laboratory. In addition to the measurements of the natural remanent magnetization (NRM) and the anisotropy of magnetic susceptibility (AMS), rock magnetic measurements were performed on a representative set of specimens to identify the magnetic mineral phases.

The NRM measurements were performed with a $2 \mathrm{G}$ Enterprises DC SQUID magnetometer. To detect any mineralogical phase changes upon thermal demagnetizing, the low field magnetic susceptibility at room temperature was measured using AGICO KLY-2S susceptibility Kappabridge after each heating step. Thermomagnetic analysis and AMS in low field were done with an AGICO MFK1-FA susceptibility Kappabridge associated with high-temperature CS-3 furnace. Hysteresis loops were studied with a Princeton Micromag VSM apparatus, but the signals were too weak to allow reliable interpretations.

The measured magnetic susceptibility $\mathrm{K}$ and the NRM intensity values are quite variable spanning several orders of magnitude and depend on the concentration of magnetic minerals. Average values are $4910^{-6} \mathrm{SI}$ and $0.09 \mathrm{~mA} \mathrm{~m}^{-1}$, respectively. High values are measured in an overwhelming majority of specimens sampled in breccias, reaching maximums of $11410^{-6} \mathrm{SI}$ for susceptibility and $1.08 \mathrm{~mA} \mathrm{~m}^{-1}$ for NRM. The Koenigsberger parameter, which is defined as a ratio of remanent magnetization to induced magnetization $\left(Q=\mathrm{NRM} /\left[K^{*} H\right]\right)$, was calculated for the maximum values of NRM and $K$. By using the appropriate IGRF as the local geomagnetic field $H$, the average value of calculated $Q$ ratio is around 0.3 . The very low values of the $Q$ ratio $(<<1)$ indicate that in situ induced magnetization would either dominate or be comparable to that of the remanent magnetization. As a result, a common assumption in magnetic anomaly interpretation is that the remanent magnetization is 


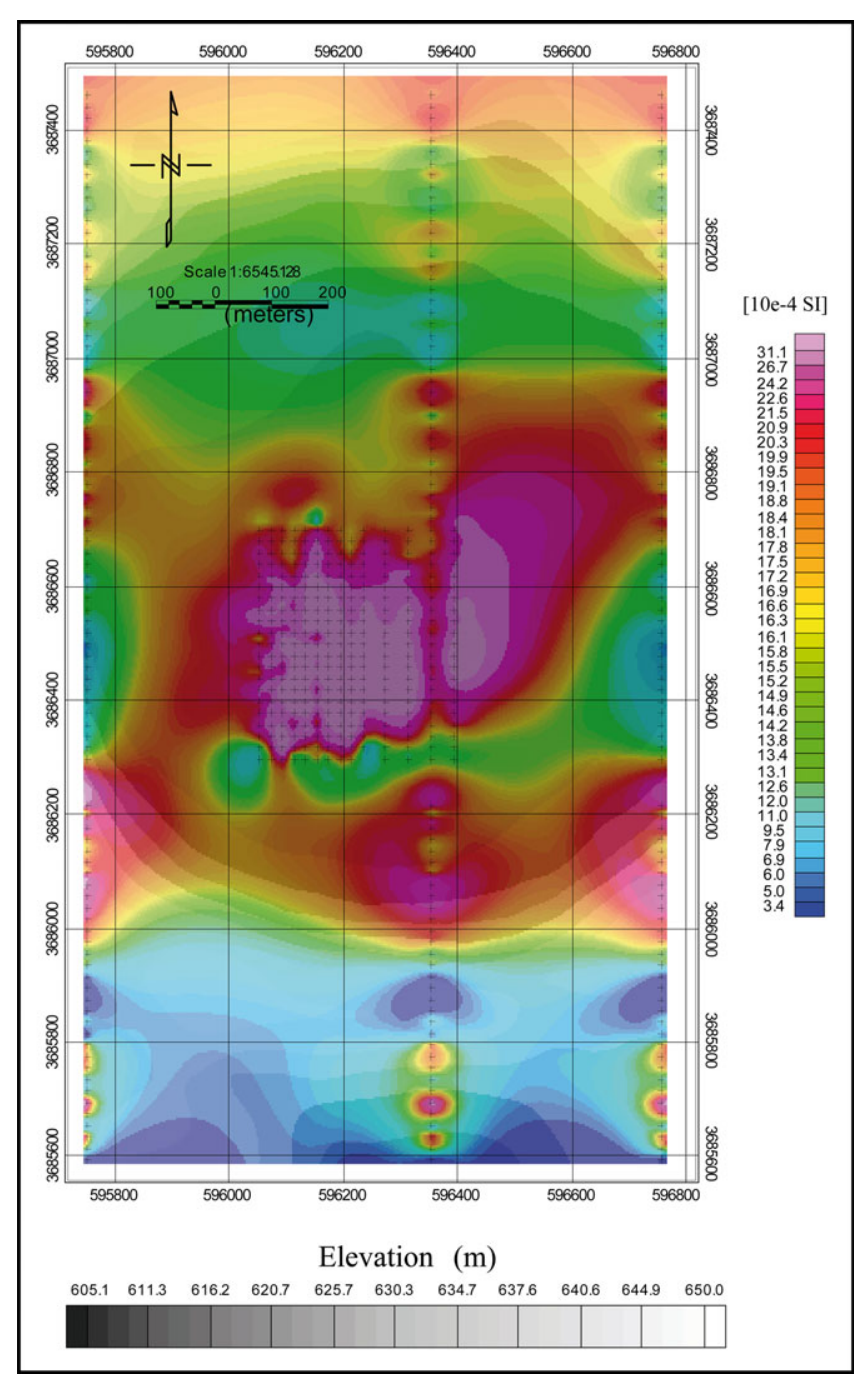

Fig. 6. Magnetic susceptibility anomaly map. The gray shaded reliefs on the maps represent a topographic composite grid of the crater.

negligible, and thus is directed in the Earth's magnetic field parallel to the induced magnetization.

Stepwise hybrid alternating field (AF) and thermal demagnetization of NRM reveals unblocking temperatures distributed from 300 to $670{ }^{\circ} \mathrm{C}$. Magnetic remanence in most specimens was totally unblocked by 630 to $660^{\circ} \mathrm{C}$ (Fig. 7a), indicating hematite-bearing rocks in the Maâdna structure. The presence of magnetite is noted in some samples by a loss of intensity with AF treatment around 20-30 mT (e.g., Sample MA84, Fig. 7a). MS underwent a weak decrease from $330{ }^{\circ} \mathrm{C}$ to $400{ }^{\circ} \mathrm{C}$ heating steps (Fig. $7 b$ ), which could result from the oxidation of magnetite (Dunlop and Ozdemir 1997). The marked increase of magnetic susceptibility at temperature higher than $400{ }^{\circ} \mathrm{C}$ results from the formation of new magnetite (Fig. 7b).

\section{Magnetic Fabric}

Studies of AMS have been widely used to understand the fabric and deformation of rocks (e.g., Tarling and Hrouda 1993). Recently, the AMS has been introduced in characterizing the deformation of rocks in context of an impact crater (Szabó and Halls 2006; Nishioka et al. 2007; Louzada et al. 2010; Misra et al. 2010; Urrutia Fucugauchi et al. 2012; Yokoyama et al. 2012). The results of laboratory shock experiments reveal that the primary effects of impact on the magnetic properties are generally a slight decrease of magnetic susceptibility (Gilder and Le Goff 2005; Gattacceca et al. 2007; Lamali et al. 2007), demagnetization or remagnetization and magnetic hardening (e.g., Rochette et al. [2003] and references therein; Gattacceca et al. 2007). It has also been demonstrated that shock waves can superimpose a new fabric on the original magnetic fabric of the target rock (e.g., Gattacceca et al. 2007; Nishioka et al. 2007; Louzada et al. 2010). Therefore, the measurement of AMS of suspected or known terrestrial impact structures may provide new insight into the process of impact cratering and shock-induced alteration.

Prior to paleomagnetic analysis, we have first studied the AMS of the Maâdna sampled lithologies (Fig. 1). To minimize the proportion of the "inverse" component in the total magnetic fabric, particularly in the case of carbonates with mixed diamagnetic and positive susceptibility contributions (Rochette 1988; Rochette et al. 1992; De Wall et al. 2000; Hamilton et al. 2004; Schmidt et al. 2009), only samples with appreciably positive measured susceptibilities, ranging between 3 to $100 \times 10^{-6} \mathrm{SI}$, were considered. These criteria lead us to disregard a number of data and in the extreme cases we have retained only one sample per site (Table 1). In those selected samples, we assume that the anisotropy signal is controlled by minute amounts of ferromagnetic minerals.

The data of a selected group of samples, at the site scale as well as at the structure scale, are analyzed using normalized tensor variability (Hext 1963; Jelinek 1978), and bivariate statistics (Henry and Le Goff 1995). For bivariate statistics (Le Goff et al. 1992), weighting by precision parameter $\mathrm{k}$ related to measurement uncertainty, is applied. The two statistical methods gave similar results. The Jelinek (1981) intensity $P^{\prime}$ and shape $T$ (varying from +1 for oblate to -1 for prolate) parameters were used to describe the magnetic fabric.

AMS results are summarized at site scale in Table 1 and Fig. 8. We observed a relatively high dispersion in AMS data, probably due to magnetocrystalline anisotropy which is prevalent in carbonates. Therefore, fabrics of the Maâdna samples are characterized by a 

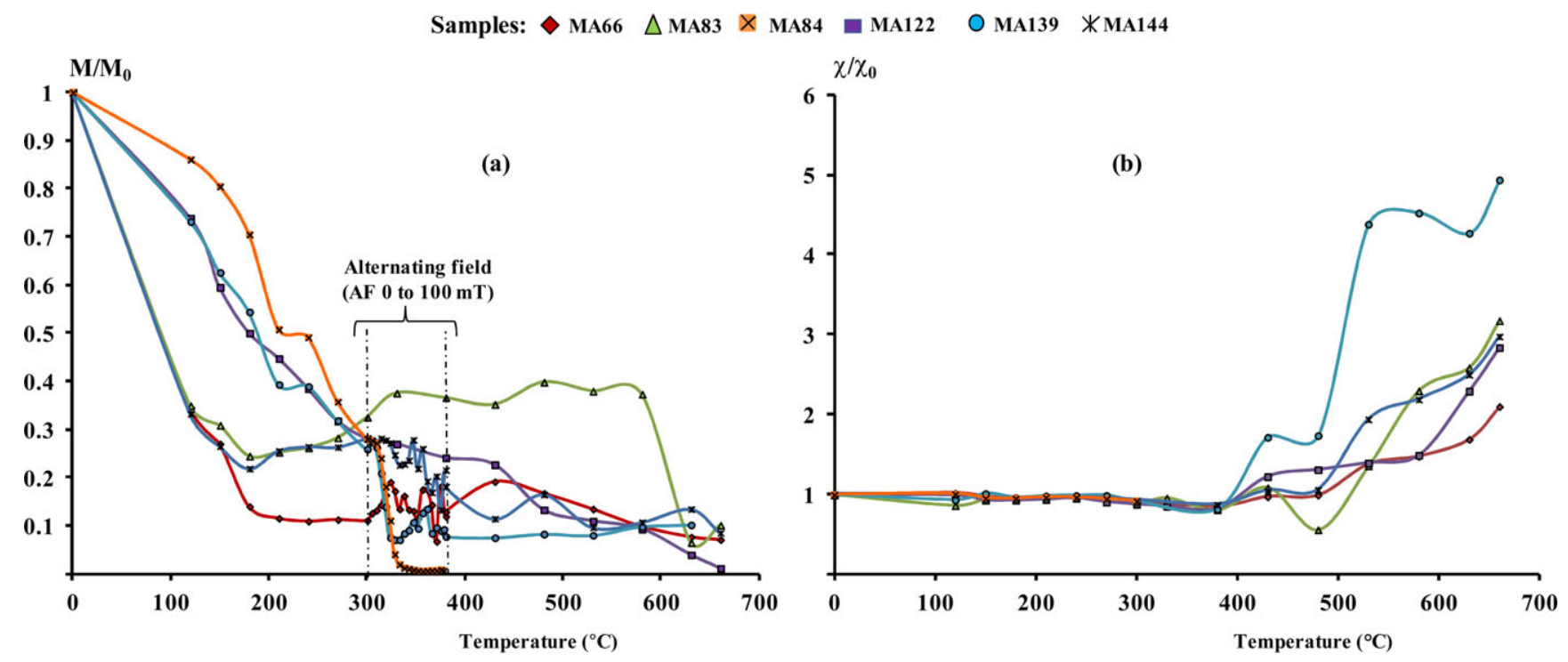

Fig. 7. a) Normalized demagnetization curve and (b) variation of the normalized magnetic susceptibility at room temperature during hybrid treatment (thermal and AF), measured on the same samples.

Table 1. AMS data according to sampling lithologies inside and outside of the Maâdna crater: Sites, number of samples $(N)$, mean susceptibility $\left(K_{\mathrm{m}}\right)$, azimuth $(A z)$, and plunge $P l$ of the principal maximum $\left(K_{1}\right)$ magnetic lineation-and minimum $\left(K_{3}\right)$-normal to the magnetic foliation-susceptibility axes in situ (normal letter) and after structural correction (italics), $\left(P^{\prime}\right)$ and $(T)$ parameters (Jelinek 1981), $\left(e_{12} / e_{13}\right)$ and $\left(e_{31} / e_{32}\right)$ Jelinek's elliptical confidence angles; for $K_{1}, e_{12}$ and $e_{13}$ refer to planes $K_{1}-K_{2}$ and $K_{1}-K_{3}$; for $K_{3}, e_{31}$ and $e_{32}$ refer to planes $K_{1}-K_{3}$ and $K_{2}-K_{3}$.

\begin{tabular}{|c|c|c|c|c|c|c|c|c|c|c|c|c|}
\hline \multirow[b]{3}{*}{ Site } & \multirow[b]{3}{*}{$N$} & \multirow[b]{3}{*}{$K_{\mathrm{m}}(\mu \mathrm{SI})$} & \multicolumn{4}{|l|}{ In situ } & \multicolumn{4}{|c|}{ After structural correction } & \multirow[b]{3}{*}{$P^{\prime}$} & \multirow[b]{3}{*}{$T$} \\
\hline & & & \multicolumn{2}{|l|}{$\overline{K_{1}}$} & \multicolumn{2}{|l|}{$K_{3}$} & \multicolumn{2}{|l|}{$\overline{K_{1}}$} & \multicolumn{2}{|l|}{$K_{3}$} & & \\
\hline & & & $A z / P l\left(^{\circ}\right)$ & $e_{12} / e_{13}\left(^{\circ}\right)$ & $A z / P l\left(^{\circ}\right)$ & $e_{31} / e_{32}\left({ }^{\circ}\right)$ & $A z / P l\left(^{\circ}\right)$ & $e_{12} / e_{13}\left({ }^{\circ}\right)$ & $A z / P l\left(^{\circ}\right)$ & $e_{31} / e_{32}\left({ }^{\circ}\right)$ & & \\
\hline $\mathrm{S} 1$ & 1 & 22.91 & $158.7 / 26.4$ & $26.9 / 24.1$ & $258.9 / 20.4$ & $24.1 / 72.1$ & $159.8 / 8.7$ & $26.9 / 24.1$ & $252.4 / 19$ & $24.1 / 72.1$ & 1.044 & -0.69 \\
\hline S3 & 11 & 58.57 & $176.4 / 42.4$ & $49.2 / 16.8$ & $81.1 / 5.7$ & $47.1 / 20.4$ & $162 / 36$ & $47.0 / 18.1$ & $259.2 / 9.9$ & $51.7 / 19.5$ & 1.013 & 0.25 \\
\hline S4 & 3 & 35.40 & $294.3 / 20.6$ & $82.0 / 75.5$ & $24.3 / 0.1$ & $86.3 / 69.1$ & $298.6 / 14.2$ & $82.0 / 75.5$ & $205.1 / 13.7$ & $86.3 / 69.1$ & 1.022 & -0.53 \\
\hline S5 & 14 & 56.31 & $357.5 / 62$ & $46.5 / 19.0$ & $120.4 / 16.1$ & $37.0 / 27.6$ & $358.5 / 49$ & $46.5 / 19.0$ & $116.3 / 22.1$ & $37.0 / 27.6$ & 1.018 & -0.31 \\
\hline S6 & 7 & 51.31 & $45.3 / 21$ & $64.3 / 39.3$ & $191 / 65.1$ & $66.9 / 29.2$ & $51.4 / 27.7$ & $64.3 / 39.3$ & $182.1 / 51.1$ & $66.9 / 29.2$ & 1.015 & -0.02 \\
\hline $\mathrm{S} 10$ & 4 & 68.12 & $330.4 / 13.6$ & $79.2 / 28.8$ & $240.2 / 0.7$ & $63.7 / 36.5$ & $332.4 / 10.8$ & $79.2 / 28.8$ & $240.5 / 10.3$ & $63.7 / 36.5$ & 1.009 & 0.49 \\
\hline \multicolumn{13}{|c|}{ Sampled "Senonian" outside the crater } \\
\hline S7 & 1 & 2.52 & $171.9 / 33.6$ & $34.3 / 22.9$ & $81.3 / 1.9$ & $23.0 / 52.2$ & $162.7 / 30.3$ & $34.3 / 22.9$ & $261 / 13$ & $23.0 / 52.2$ & 1.579 & -0.18 \\
\hline S9 & 10 & 20.57 & $237.3 / 27.5$ & $54.5 / 35.9$ & $122.9 / 38.4$ & $67.5 / 34.5$ & $237.7 / 28$ & $54.5 / 35.9$ & $122.3 / 38.9$ & $67.5 / 34.5$ & 1.033 & -0.21 \\
\hline
\end{tabular}

great variability in the orientation of the principal susceptibility axes $\left(K_{1}\right.$ and $\left.K_{3}\right)$ and shape parameters estimates, with high elliptical confidence angle values (Fig. 8, Table 1). Otherwise, high dispersion of site mean standard errors is linked to high dispersion of $K_{1}$ and $K_{3}$ axes, as visible on the representative ConiacianMaastrichtian sites compared to those in the Pliocene (Fig. 8a, Table 1). Mean site susceptibility varies between 2.5 and $68 \times 10^{-6}$ SI units (Table 1). Apart from site 3 (S3) in the Coniacian-Maastrichtian, the highest $K_{\mathrm{m}}$ values are recorded in the Pliocene limestone breccias inside and outside the crater (e.g., S5, S6, S8, and S10, Table 1). Furthermore, the Pliocene samples display low values of anisotropy degree $P^{\prime}$, ranging between 1.009 and 1.003. In contrast, the ConiacianMaastrichtian sites have the highest value of $P^{\prime}$, 


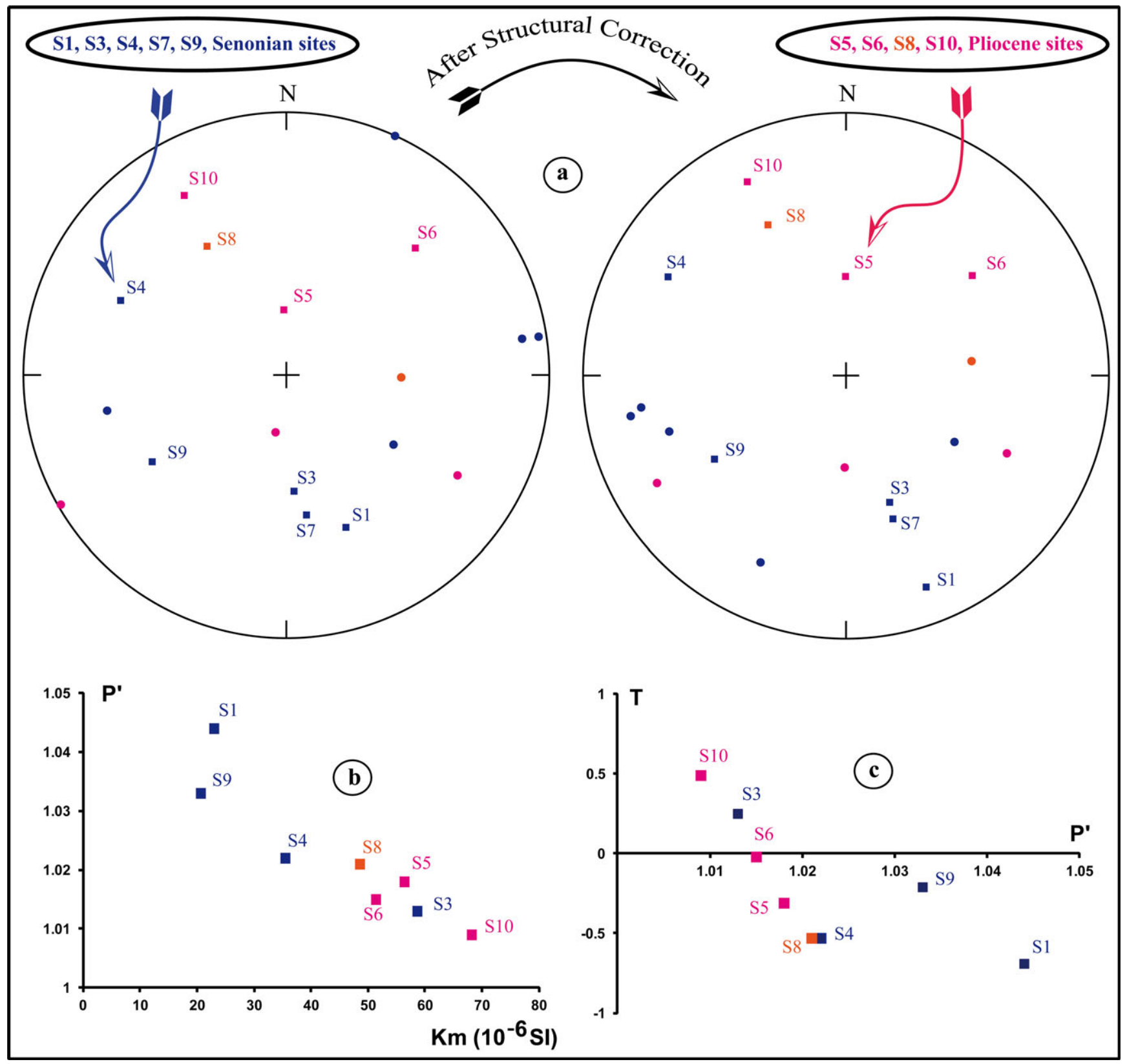

Fig. 8. AMS data. a) Maximum ( $K_{1}$, squares) and minimum ( $K_{3}$, circles) principal susceptibility axes from the Maâdna structure sampled sites (stereographic projection in the lower hemisphere, in situ and after structural correction). b) Plots of $P^{\prime}$ against $K_{\mathrm{m}}$ (c) and of the shape parameter $T$ against $P^{\prime}$ (Jelinek 1981).

reaching about 1.579 (e.g., S1 and S7; Figs. 8b and 8c; Table 1).

\section{Paleomagnetic Analysis}

We conducted a paleomagnetic study of oriented rocks from the Maâdna structure for various reasons. First, we expected to obtain a paleomagnetic age with an identification of any potential magnetic shock indicators. Second, we reviewed the magneto-structural emplacement of the Maâdna crater by combining AMS and paleomagnetic data.

Paleomagnetic studies may be useful for dating impacts (Deutsch and Scharer 1994). Several studies have already confirmed the feasibility of paleomagnetic dating of impact structures (e.g., Robertson 1967; Currie and Larochelle 1969; Pohl and Soffel 1971, 1977; Cisowski 1988; Schmidt and Williams 1991; Pesonen 


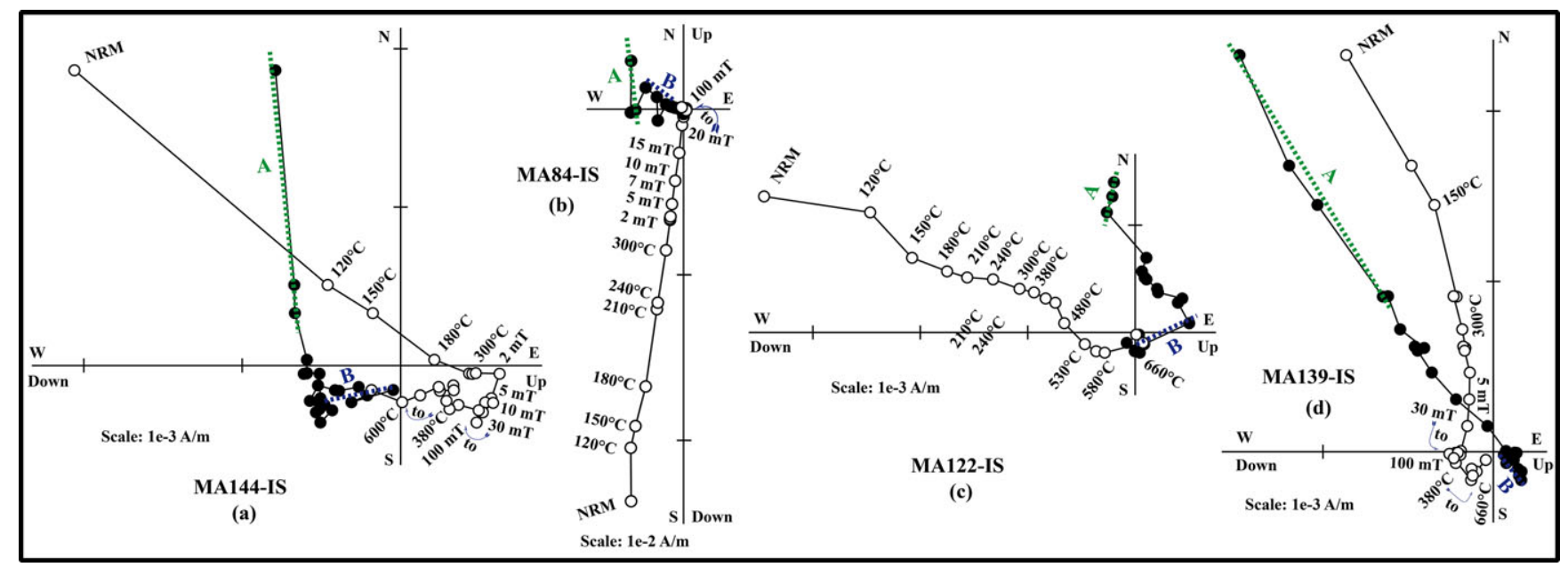

Fig. 9. Orthogonal vector plots (full symbols: horizontal plane, open symbols: vertical plane) in situ (IS): Representative samples from the Maâdna rocks (a-MA144, b-MA84, c-MA122, d-MA139).

et al. 1992). In general, the recorded re- or demagnetization may be due to the reduction of remanent or induced magnetization intensity or randomization of primary remanence components. During the brief period of shock release, just at the time of impact, a new shock remanent magnetization (SRM) may also be acquired owing to the presence of an ambient geomagnetic field (e.g., Gattacceca et al. 2007; Tikoo et al. 2015).

To characterize the magnetic behavior of our samples, we have carried out a pilot study by subjecting a set of specimens to stepwise AF (up to $140 \mathrm{mT}$ ) and thermal demagnetization (up to $660{ }^{\circ} \mathrm{C}$ ). These preliminary treatments led us to choose stepwise hybrid AF/Thermal demagnetization as the most suitable method for a complete demagnetization, while reducing thermochemical alteration. For most samples, after removing AF resistant secondary magnetization at $300{ }^{\circ} \mathrm{C}$, the samples were subjected to $\mathrm{AF}$ demagnetization up to about $140 \mathrm{mT}$ and followed again by thermal demagnetization up to $660^{\circ} \mathrm{C}$. Figure 9 shows the demagnetization data of representative samples (Wilson and Everitt 1963; Zijderveld 1967). The data were processed with PaleoMac software (Cogné 2003). The direction of the different components of the NRM in each specimen was computed using principal component analysis (Kirshvink 1980). The remagnetization circles method (Halls 1978; McFadden and McElhinny 1988) was also used. Fisher's (1953) statistics and their bivariate form (Le Goff et al. 1992) were used to determine the mean direction of the NRM components within each site. The method that involves plotting subtracted vectors on an equal area stereographic projection, at each stage in the progressive demagnetization process, was also tested.
The vector end-point demagnetization diagrams analysis was used to isolate and establish the stability of all significant magnetization components (Fig. 9). The samples reacted in a different way against treatment procedures but mostly they exhibit two types of magnetic behavior especially at high temperatures. The first one is that the thermal demagnetization reveals a single stable and origin trending magnetization component (Figs. 9b and 9c). The second one indicates an evolution of the direction along great circle paths on equal area projection or a curved segment on the Zijderveld diagrams (Figs. 9a and 9d). This could be interpreted as a partial superposition of unblocking temperature spectra of at least two components leading to incoherent intersection of great circles. A few samples were discarded due to mineral alterations, and the first component "A" was isolated at temperatures lower than $150-200{ }^{\circ} \mathrm{C}$ in all sites. Mainly above $300{ }^{\circ} \mathrm{C}$ and in excess of $20 \mathrm{mT}$, stepwise $\mathrm{AF} /$ thermal demagnetization was successful in isolating a stable characteristic remanent magnetization (ChRM) component "B" of either normal or reverse polarity at eight sites (Fig. 9; Figs. 10a and 10b; Table 2).

The low temperature "A" component (visible both in the Pliocene and the Coniacian-Maastrichtian samples, Table 2) provides well-defined mean directions at the site level, all with normal polarities (Figs. 10a and 10b). The average in situ direction of the 10 sites (number of sample, $N=93$ ) yielded $D=6^{\circ}, I=48^{\circ}$ with corresponding Fisher parameters $k=85, \alpha_{9}=5.3^{\circ}$ (Table 2). This not significantly different from the present-day geocentric axial dipole (GAD) direction $\left(D=0^{\circ}, I=49^{\circ}\right)$. Moreover, the fold test shows that the best grouping occurs at $0 \%$ unfolding (see Fig. 12a). Therefore, it is most likely that this direction in the 


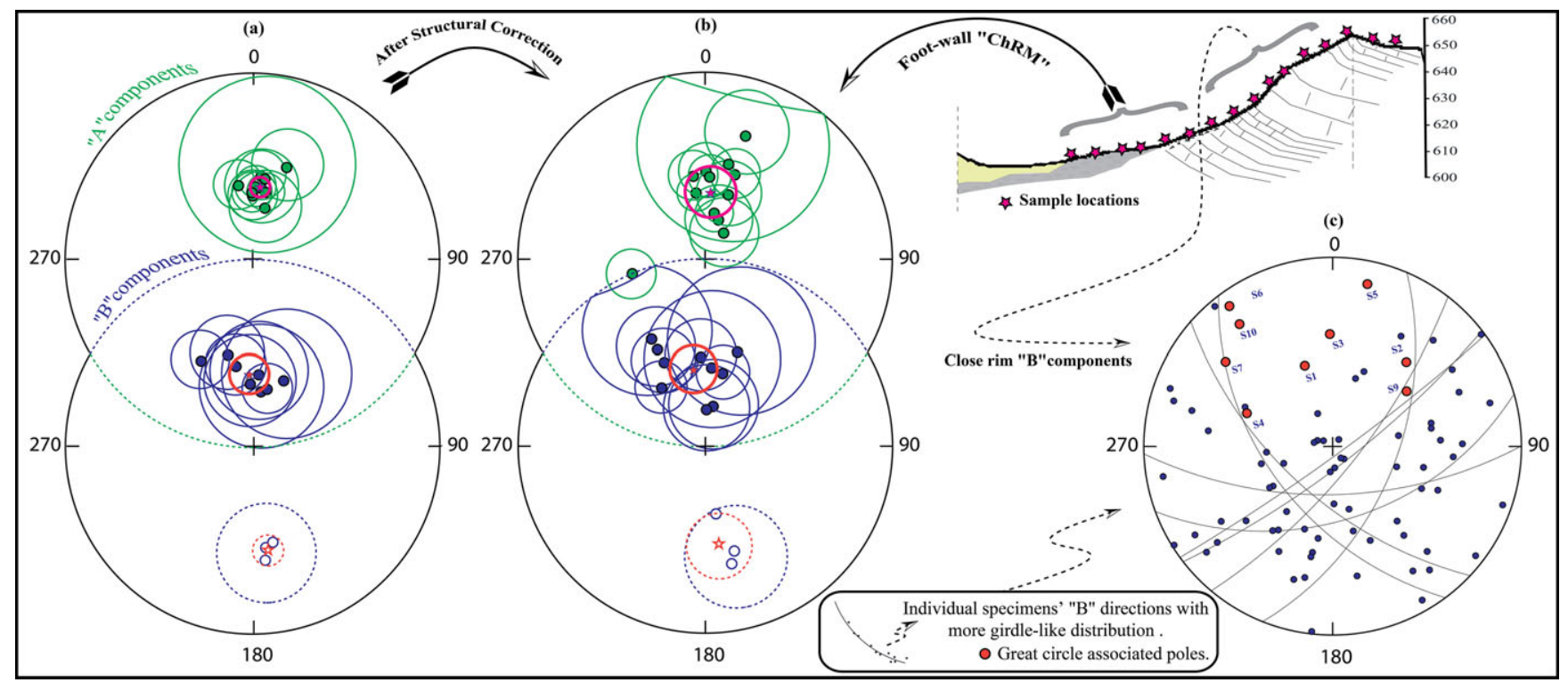

Fig. 10. Mean paleomagnetic directions of the "A" and "B" isolated components and their associated 95\% confidence cone, before (a) and after (b) structural correction, for the all studied formations (stereographic projection-open symbols and confidence cone with dotted line for the upper hemisphere; full symbols and confidence cone with continuous line for the lower hemisphere); (c) Individual specimens "B" directions with more girdle-like distribution and their estimated great circles and corresponding poles using Halls's (1978) method with a sketched profile of paleomagnetic sampling from the rim to the foot wall of the crater at each site.

Coniacian-Maastrichtian is a Brunhes age secondary magnetization of viscous or weathering origin. In the Pliocene it could be either the same type of magnetization or a primary magnetization (likely chemical remanent magnetization-CRM) of Pliocene age in normal polarity.

The ChRM "B" shows mostly normal polarity, with reverse polarity identified in two ConiacianMaastrichtian (S2, S3) sites and one Pliocene (S6) site, all inside the crater. These sites bear also normal polarities. The average in situ direction of the 8 normal sites yielded for $N=52, D=355.8^{\circ}, I=47.9^{\circ}, k=29, \alpha_{95}=10.5^{\circ}$ (Fig. 10, Table 2). The reverse polarity samples yielded a mean in situ direction of $D=172.6^{\circ}, I=-31.6^{\circ}$, $k=297, \alpha_{95}=7.2^{\circ}$, basically for $N=11$ (Table 2). For the other specimens, the magnetization direction evolves along a great circle path on the projection sphere. Unfortunately, the analysis of remagnetization circles using the method of Halls (1978) and the use of McFadden and McElhinny (1988) approach in integrating great circles and ChRM "B" data failed.

Some specimens, mostly sampled in the ConiacianMaastrichtian limestone, show a ChRM "B" with a high degree of variation, in declination as well as in inclination at site scale. Moreover, this specific behavior is observed on the specimens collected in highly dipping strata (see Figs. 1 and 2a). In Fig. 10c, we show for each site, these individual specimens "B" directions with more girdle-like distribution and their estimated great circles and corresponding poles using Halls's (1978) method. However, this behavior may be considered as a result of parasitic effects due to low magnetization or a tilting due to the tectonic event that occurred during the collapse of strata within the Maâdna structure. As sketched in Fig. 10, this specific versus regular behavior of ChRM " $\mathrm{B}$ " is clearly pointed out across the sampled profile along with the crater wall.

A negative conglomerate or randomness test result (Watson 1956) was obtained in all brecciated Pliocene conglomerates (Sites 5, 6, 8, 10; Fig. 1) since the ChRM has a similar orientation in the elements and in their matrix. The reversal test (McFadden and McElhinny 1990) in which the mean directions of the reversed and normal data sets and $A_{95}$ are utilized, is negative before structural correction (Table 3). Still, while the normal polarity "B" direction $\left(D=-4.2^{\circ}, I=47.9^{\circ}, k=29\right.$, $\alpha_{95}=10.5^{\circ}$, Table 2) is again undistinguishable from present-day GAD and "A" direction, the well-defined reverse polarity mean $\left(D=172.6^{\circ}, I=-31.6^{\circ}, k=297\right.$, $\alpha_{95}=7.2^{\circ}$, Table 2) does depart significantly from it. It is noteworthy that the reverse directions from samples of these three sites are found in the ConiacianMaastrichtian strata within the crater rim. The fold test (McElhinny 1964; McFadden 1990; Table 3) is statistically significant for both components ("A" and "B"), giving the best clustering for $0 \%$ unfolding 
Table 2. Paleomagnetic data according to sampling lithologies inside and outside of the Maâdna crater: Sites, number of samples $(N)$, declination $(D)$, inclination $(I)$ and corresponding Fisher's (1953) parameters $(k)$ and $\left(\alpha_{95}\right)$ in situ (normal letter) and after structural correction (italics), longitude $(L g)$, latitude $(L t)$ and corresponding Fisher's (1953) parameters $(K)$ and $\left(A_{95}\right)$ of the associated VGP or paleomagnetic pole in situ (normal letter) or/ and after structural correction (italics).

\begin{tabular}{|c|c|c|c|c|c|c|c|c|c|c|c|c|c|}
\hline \multirow[b]{2}{*}{ Site } & \multirow[b]{2}{*}{$N$} & \multicolumn{4}{|c|}{ In situ } & \multicolumn{4}{|c|}{ After structural correction } & \multicolumn{4}{|c|}{ Poles coordinates } \\
\hline & & $D\left(^{\circ}\right)$ & $I\left(^{\circ}\right)$ & $k$ & $\alpha_{95}\left({ }^{\circ}\right)$ & $D\left(^{\circ}\right)$ & $I\left(^{\circ}\right)$ & $k$ & $\alpha_{95}\left({ }^{\circ}\right)$ & $\operatorname{Lg}\left({ }^{\circ} \mathrm{E}\right)$ & $L t\left({ }^{\circ} \mathrm{S}\right)$ & $K$ & $A_{95}\left({ }^{\circ}\right)$ \\
\hline
\end{tabular}

Inside and outside the crater

Component A

Sampled "Senonian" inside the crater

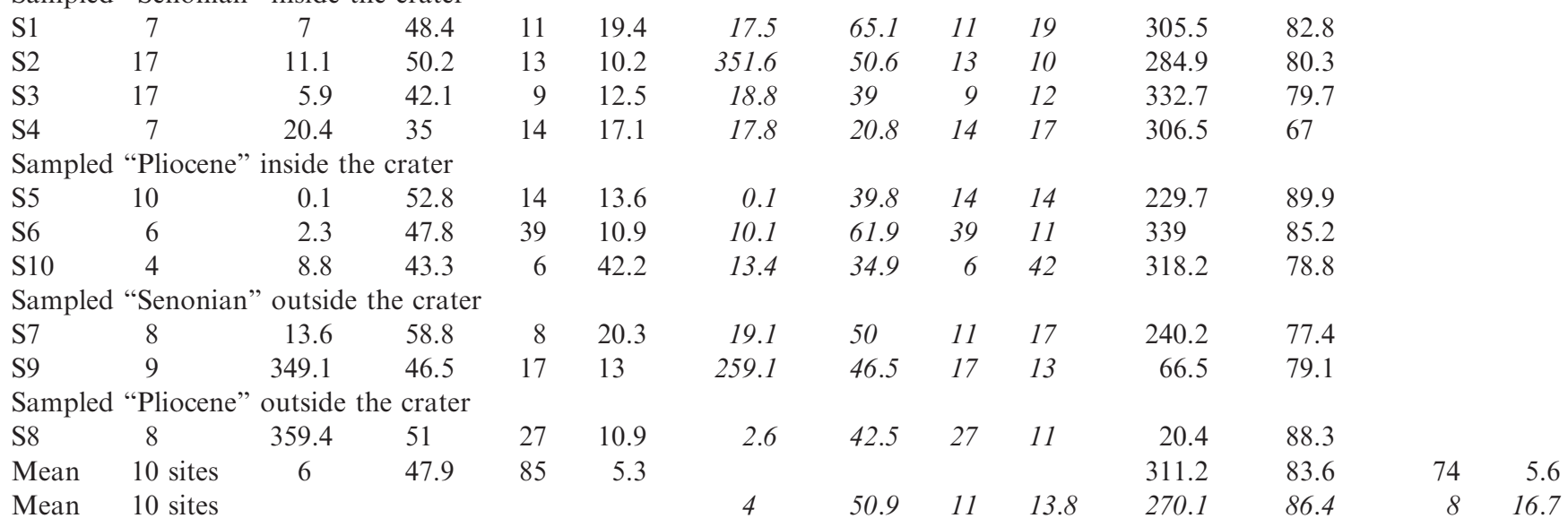

Inside and outside the crater

Component B (Normal polarity)

Senonian

\begin{tabular}{|c|c|c|c|c|c|c|c|c|c|c|c|c|c|}
\hline S1 & 6 & 3.4 & 47.9 & 9 & 25.6 & 11.7 & 65.1 & 9 & 25.6 & 329 & 84.8 & & \\
\hline S2 & 11 & 347.1 & 42.5 & 10 & 15.5 & 334.4 & 37.1 & 10 & 15.5 & 59.8 & 75.7 & & \\
\hline $\mathrm{S} 3$ & 8 & 343.9 & 36.1 & 11 & 17.8 & 357.6 & 39.1 & 11 & 17.5 & 55.2 & 70.4 & & \\
\hline S4 & 7 & 23.8 & 47.9 & 4 & 33.2 & 19.1 & 33.9 & 4 & 33.2 & 279.6 & 69.2 & & \\
\hline S7 & 4 & 328.1 & 33.4 & 46 & 13.7 & 333.7 & 24.9 & 13 & 26.9 & 74.1 & 57.8 & & \\
\hline \multicolumn{14}{|c|}{ Pliocene } \\
\hline S5 & 4 & 6.6 & 57.2 & 8 & 33.7 & 5 & 44.3 & 8 & 33.7 & 232.1 & 83 & & \\
\hline S6 & 2 & 356.1 & 53 & - & - & 2.7 & 67.5 & - & - & 99.4 & 86.7 & & \\
\hline S8 & 10 & 12.4 & 55.2 & 13 & 13.9 & 13.7 & 46.3 & 13 & 13.9 & 257.2 & 79.5 & & \\
\hline Mean & 8 sites & 355.8 & 47.9 & 29 & 10.5 & & & & & 39.2 & 85.4 & 22 & 12 \\
\hline Mean & 8 sites & & & & & 351.8 & 45.2 & 16 & 12.3 & 57.6 & 82 & 14 & 13.4 \\
\hline \multicolumn{14}{|c|}{ Inside the crater } \\
\hline \multicolumn{14}{|c|}{ Component B (Reverse polarity) } \\
\hline \multicolumn{14}{|c|}{ Senonian } \\
\hline S2 & 2 & 174.6 & -27 & - & - & 167 & -24.5 & - & - & 19.7 & 70.4 & & \\
\hline S3 & 7 & 173.7 & -32.8 & 8 & 22.8 & 185.5 & -33 & 8 & 23 & 25.6 & 73.5 & & \\
\hline \multicolumn{14}{|c|}{ Pliocene } \\
\hline S6 & 2 & 169.3 & -34.8 & - & - & 170.4 & -49.7 & - & - & 40.8 & 72.9 & & \\
\hline Mean & 3 sites & 172.6 & -31.6 & 297 & 7.2 & & & & & 28.3 & 72.5 & 476 & 5.7 \\
\hline Mean & 3 sites & & & & & 171.6 & -34.5 & 36 & 16 & 34.3 & 74.3 & 46 & 13.6 \\
\hline
\end{tabular}

(postfolding). A progressive unfolding clearly confirms a postfolding acquisition of the three components ("A" and "B" with its normal and reverse polarity; Figs. 11ac). Therefore, acquisition of the magnetization is clearly postfolding. The in situ negative reversal test leads to reject as well a primary magnetization in sense of Holt and Kirschvink (1995) criterion. The ChRM " $\mathrm{B}$ " is therefore a remagnetization of the ConiacianMaastrichtian formation postdating the tilting and thus the crater emplacement. In most cases it has been isolated with thermal treatment up to very high temperature and is clearly not due to a thermal effect. Hence it could not be a thermoremanent magnetization (TRM). It is necessarily a CRM that may set a 
Table 3. Summary of the paleomagnetic tests (reversal and fold tests) of the "B" directions and "A" directions in the corresponding sites.

\begin{tabular}{|c|c|c|c|c|c|c|c|c|c|c|}
\hline \multirow{2}{*}{$\begin{array}{l}\text { Reversal test } \\
\text { Sites components }\end{array}$} & & & \multicolumn{5}{|c|}{$\begin{array}{l}\text { McFadden and McElhinny } 1990 \\
\text { In situ }\end{array}$} & \multicolumn{3}{|c|}{ After structural correction } \\
\hline & & & & \multirow{2}{*}{$\begin{array}{l}\gamma_{c}(95 \%) \\
17.4^{\circ}\end{array}$} & \multicolumn{3}{|c|}{ Test classification } & $\gamma$ & $v_{c}(95 \%)$ & Test classification \\
\hline All normal and re & verse $\mathrm{pc}$ & larities & & & $\mathrm{Neg}$ & ative & & $3.89^{\circ}$ & $20.7^{\circ}$ & Indeterminate "I" \\
\hline \multirow{2}{*}{$\begin{array}{l}\text { Fold test } \\
\text { Sites components }\end{array}$} & \multicolumn{5}{|c|}{ McElhinny (1964) } & \multicolumn{5}{|c|}{ McFadden (1990) } \\
\hline & $k_{1} / k_{2}$ & $\gamma_{c}(95 \%)$ & $\gamma_{\mathrm{c}}(99 \%)$ & \multicolumn{2}{|c|}{ Test classification } & $\chi_{i}^{2}(\mathrm{IS})$ & $\chi_{\mathrm{i}}^{2}(\mathrm{TC})$ & $\chi_{\text {ic }}(95 \%)$ & $\chi_{\text {ic }}(99 \%)$ & Test classification \\
\hline "A" & 7.72 & 2.17 & 3.03 & \multirow{2}{*}{\multicolumn{2}{|c|}{$\begin{array}{l}\text { Negative } \\
\text { Indeterminate }\end{array}$}} & 0.14 & 9.68 & 3.68 & 5.12 & Negative \\
\hline $\begin{array}{l}\text { ChRM "B" } \\
\text { (normal) }\end{array}$ & 1.74 & $2.41^{\circ}$ & $3.56^{\circ}$ & & & 1.00 & 5.35 & 3.29 & 4.56 & Negative \\
\hline $\begin{array}{c}\text { ChRM "B" } \\
\text { (negative) }\end{array}$ & 8.29 & 6.39 & 15.98 & \multicolumn{2}{|l|}{ Negative } & 0.13 & 2.87 & 2.07 & 2.66 & Negative \\
\hline
\end{tabular}
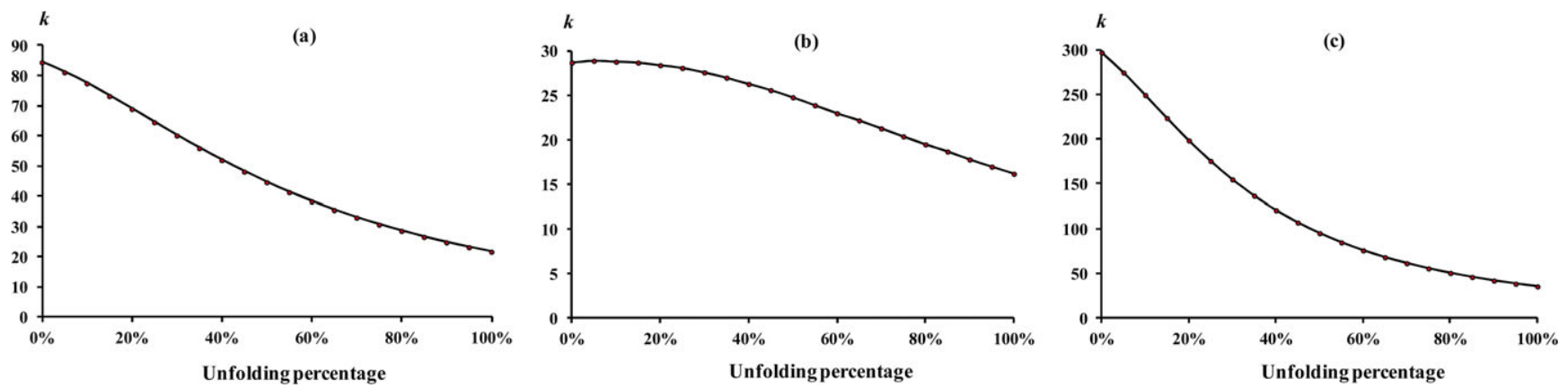

Fig. 11. Variation of the Fisher's (1953) precision parameter k during progressive unfolding applied to mean-site directions for the Maâdna sampling sites (a-"A" directions, b-"B" normal directions, c-"B" reverse directions).

minimum age for the formation of the Maâdna structure. We will discuss its possible age below.

\section{DISCUSSION}

\section{Geophysical Survey Data}

In most impact structures for which data are available, the potential field anomalies, such as circular gravity low and magnetic low or high, depend on the erosion level and on the amount of deformation (Henkel et al. 2002). The amplitude of the negative gravity anomaly mostly increases with crater diameter while the magnetic anomaly depends on several parameters mainly related to the magnetic properties discrepancies of the rocks and the direction of the magnetization. In the case of the Maâdna crater, the magnetic anomaly is in the $10 \mathrm{nT}$ range, in accordance with the weakly magnetic limestone lithology. In comparison, in the case of the small Monturaqui crater (Ugalde et al. 2007), the magnetic anomaly is larger, in the order of $100 \mathrm{nT}$, in agreement with a more magnetic granitic lithology than in the case of Maâdna, whereas the Bouguer anomaly is of the same order (i.e., of
$2 \mathrm{mGal}$ in Monturaqui and of $6 \mathrm{mGal}$ in Maâdna). To explore the possible structures responsible for the observed anomalies, we have modeled them using the GM-SYS software (Oasis Montaj Geosoft) which allows geological interactive forward modeling. As a result, a joint gravimetric and magnetic inversion was carried out with an implementation of a $2^{1 / 2} \mathrm{D}$ forward modeling found on the expressions of Talwani and Heirtzler (1964), Rasmussen and Pedersen (1979), and on the algorithm proposed by Won and Bevis (1987).

The $2^{1 / 2} \mathrm{D}$ model calculations using an inversion algorithm are plotted to match a magnetic and gravimetric profiles $\mathrm{AA}^{\prime}$ (Fig. 5B-1), taken from the map from $\mathrm{N}$ to $\mathrm{S}$ across the center of the structure and most important magnetic and gravimetric anomalies (Fig. 5). It is important to note that the proposed model (Fig. 12) is built upon the experimental information extracted from the filtered magnetic and gravimetric maps shown in Figs. 5A-2 and 5B-2. This model also extends to infinite along the profile to eliminate some edge effects.

The magnetic profile (Fig. 12) shows that the central zone is characterized by a sharp anomaly caused by a high susceptibility rock/body indicating a 


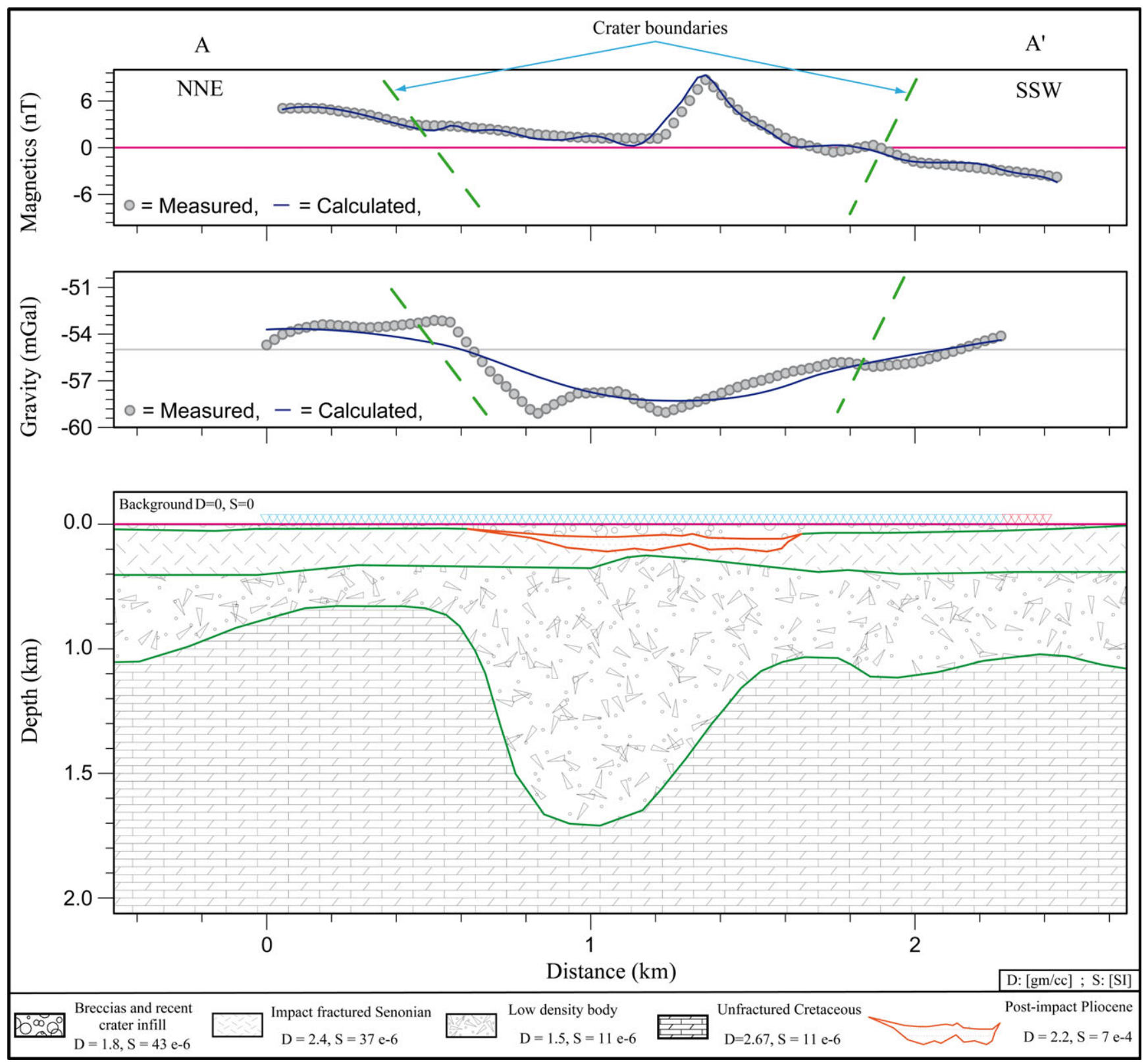

Fig. 12. Geomodeling of the Maâdna structure based on joint magnetic and gravimetric inversion, and data sampled from N-S cross section through magnetic and gravity gridded maps (see $\mathrm{AA}^{\prime}$ in Fig. 5B-1). Calculations are made taking into account geomagnetic parameters of the study area, such as the declination and inclination of the magnetic induction vector (IGRF), the density and magnetic susceptibility of the host rocks, the topography, as well as geometry of the boundary layers. This allows getting distribution of the simplest types of gravitational and magnetic sources, after suppression effect of topography. The layers with density and magnetization properties are represented by the filling pattern. To get a good fit with both the observed gravity and magnetic profiles, two bodies with a high susceptibility and low density were introduced below the observed magnetic high and gravity low, respectively.

concentration of magnetite in the SW part of the crater depression. This magnetite enrichment is possibly related to a contamination of the underlying deposit by the Maâdna fill material. However, a small positive anomaly appears inside this anomaly, indicating the presence of some more magnetized bodies at shallow depths (Fig. 12). This anomaly is surrounded on both sides by negative anomalies. The northern zone corresponds to a very weak negative magnetic anomaly while the southern zone presents a wide negative anomaly of high amplitude. The latter is also characterized by a lower gradient comparatively to the 
high ones delimiting the central positive anomalies. According to our spectral analysis and Euler deconvolution depth estimation, the central positive anomaly implies the occurrence of a magnetic body at 100 meter of NS extension. Its extension in depth is not well constrained by our model, which highlights a body density of about $2.6 \mathrm{~g} \mathrm{~mL}^{-1}$ and a magnetic susceptibility of $7 \times 10^{-4}$ SI at depth to top reaching roughly $100 \mathrm{~m}$ (Fig. 12).

The gravimetric profile (Fig. 12) presents in its central part a sharp negative anomaly related to the presence of an important low density body. This anomaly clearly characterizes the Maâdna depression and is bordered on both sides by positive anomalies that could be associated with high density bodies. The northern part is in fact characterized by a strong and wide positive anomaly with a high gradient on its limits demonstrating the density discontinuities between each body.

As main results, the magnetic and gravimetric profiles (Fig. 12) evidence a succession of positive and negative anomalies. This could suggest that the causative material may be at least in part identical. The model basically shows complex distributions of the causative anomaly sources around the Maâdna depression which are not exceeding mostly $1 \mathrm{~km}$ in depth. Reaching this depth, they encounter everywhere the surrounding limestones attributed to regional basement of the Triassic province (Askri et al. 1995). The shallowest magnetized zone of the central part is clearly identified by the soil magnetic susceptibility measurements (Fig. 6) as recently deposited material and represents the first constrained layer in the model (Fig. 12). Magnetic enhancement of this soil like sediment may be due to pedogenesis and wind-blown iron oxides. The gravity constrained model implies the presence of a relatively deep pre-Coniacian low density formation. This formation reaches a maximum thickness below the crater, which could mean impactfractured Cretaceous sediments, or a salt diapir injected below the structure. The fact that a low density body is also needed north of the crater pleads toward the diapir hypothesis. We therefore suggest that the alternative hypothesis of a salt dome "diapir" accompanied by a possible hydrothermal activity is a viable alternative to explain the observed geophysical anomalies.

\section{Paleomagnetic and AMS Data}

In most cases, the weak anisotropy renders hazardous the definition of an accurate ellipsoid shape in both Coniacian-Maastrichtian and Pliocene lithologies (Fig. 8c). A high scatter of anisotropy axes was also observed in both lithologies despite the higher susceptibility of the Pliocene brecciated limestone inside and outside the crater (Fig. 8, Table 1). Given that susceptibility measures the content of iron-bearing minerals, the Pliocene breccias seems to have high iron oxide content compared to Coniacian-Maastrichtian limestone. There is a rough negative relationship between $K_{\mathrm{m}}$ and $P^{\prime}$ (Fig. 8b). In our case recorded $P^{\prime}$ values, inversely proportional to $K_{\mathrm{m}}$, are low in Pliocene and higher in Coniacian-Maastrichtian, suggesting an effect of mixture between diamagnetic and paramagnetic/ferromagnetic contribution (Rochette et al. 1992). In general, it seems that the AMS signal is too weak to allow robust interpretations.

From the original paleomagnetic investigation at Maâdna carter, overall two components were identified in nearly all samples (Fig. 9). The component "A" direction, close to the recent field and with only normal polarity, is interpreted as Brunhes age $(<800 \mathrm{ka})$ postcrater remagnetization. The component " $\mathrm{B}$ " of either normal or reverse polarity was isolated at high temperatures in eight sites (Fig. 10; Table 2). The normal polarity "B" component could be the Pliocene primary magnetization, indistinguishable from " $\mathrm{A}$ " component. Its corresponding virtual geomagnetic pole (VGP) $\left(N=52, \quad L g=39.2^{\circ} \mathrm{E}, \quad L t=85.8^{\circ} \mathrm{S}, \quad K=22\right.$, $A_{95}=12^{\circ}$; see Table 2 and Fig. 13) is close to paleomagnetic poles for other formations in the Sahara platform, such as those recorded in the Paleozoic formation of the 1llizi Basin and interpreted as a Cenozoic magnetic overprint (Lamali et al. 2014; and references therein). The comparison with the African Apparent Polar Wander Path "APWP" (e.g., the first paleopole coordinates " $L g=356.9^{\circ} \mathrm{E}, \quad L t=86.2^{\circ} \mathrm{S}$ " from Besse and Courtillot (2002) compilation, corresponding to $3.1 \mathrm{Ma}$ ) is consistent with a Pliocene age of this magnetization (Fig. 13). Because of the lack in precision of the APWP to provide an absolute age determination, especially around its CretaceousCenozoic segment, the window of ages should be extended to the entire Pliocene period (2.6-5.3 Ma, Zanclean - Piacenzian; Gradstein et al. 2004). Consequently, this normal component, necessarily a CRM, may probably date the first emplacement of the Maâdna depression.

The reverse component could be a Cenozoic remagnetization commonly observed in the Sahara platform (Lamali et al. 2014; and references therein). The interpolation of the corresponding in situ paleomagnetic pole $\left(N=11, L g=28.3^{\circ} \mathrm{E}, L t=72.5^{\circ} \mathrm{S}\right.$, $K=476, A_{95}=5.7^{\circ}$; see Table 2 and Fig. 13) with the African APWP, using compilation in Lamali et al. (2013), gives values close paleopole coordinates " $L g=36.1^{\circ} \mathrm{E}, \quad L t=73.1^{\circ} \mathrm{S} . " \quad$ This corresponds to $\sim 60 \mathrm{Ma}$ (Besse and Courtillot 2002). This highlights an age window which is at least close to the Middle 


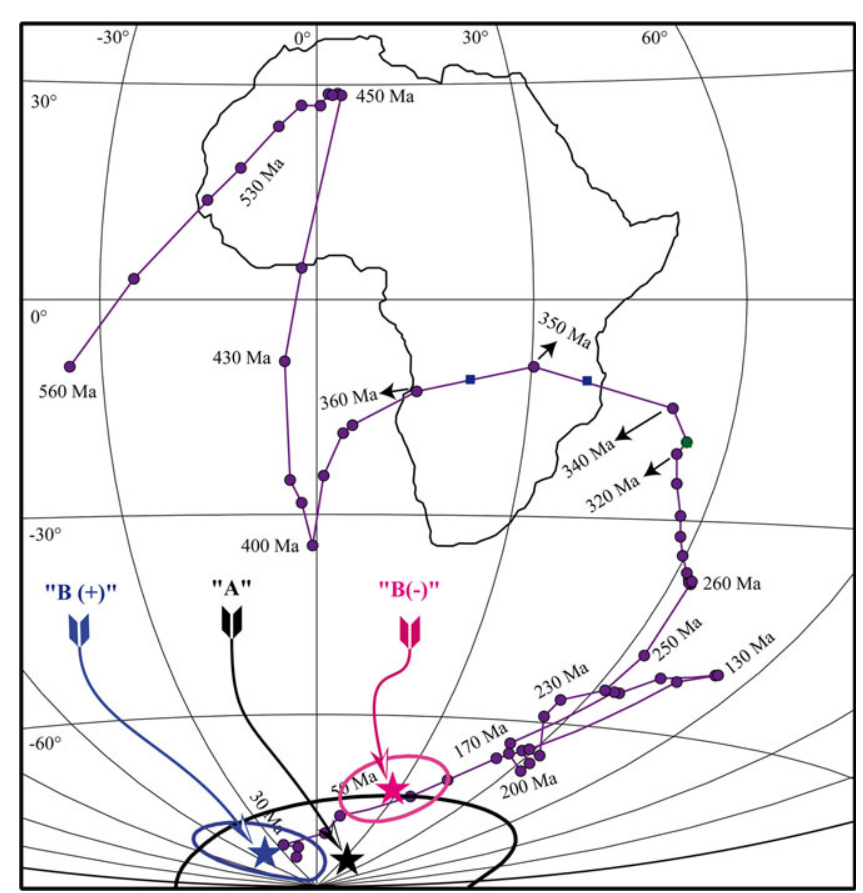

Fig. 13. For the component "A" directions, "B" normal directions, and "B" reverse directions, Hammer-Attof projections of paleomagnetic poles with associated confidence cone (stars), interpolated within the African APWPs (circles) "560-0 Ma" (Besse and Courtillot 2002; Domeier et al. 2012, Lamali et al. 2013, 2014).

Paleocene period (Selandian, Gradstein et al. 2004). This result departs slightly from our results for the normal polarity magnetization. However, all the attempted paleomagnetic tests reject the primary character of the magnetization. Using the McFadden and McElhinny (1990) method, a comparison of the normal and reverse polarity, calculated before structural correction, indicates that they are relatively close with an angular difference of about $16.6^{\circ}$ after reduction to same polarity. However, they are statistically different in term of fisherian means (Table 2). This difference could be associated with the complex deformation in Maâdna structure.

\section{Discussion on the Age and Origin of the Crater-Like Structure}

Let us recall that the Maâdna crater is situated in the "Region of Dayas," from which etymologically comes the original Arabic name of Daeit El Maâdna (Talemzane). It is also known that the "Dayas" are interpreted as karstic depressions developed in regionally distributed Neogene carbonate-rich units. Upon approach, the Maâdna crater offers a similar panorama, as well as a distinct morphological similarity to the medium-size impact structures, such as Tswaing crater in South Africa, Wolfe Creek crater in Australia, Meteor Crater in USA, Lonar crater in India, Roter Kamm crater in Namibia, Tenoumer crater in Mauritania, Lake Isli in Morroco, Richat dome in Mauritania, etc. All of these structures are formed into nearly flat-lying sedimentary and/or volcanic and/or crystalline rocks, and currently listed as a confirmed, possible, or rejected impact structures. Hence, the crater-like structures require meticulous observations and interpretations to state on their diverse origin which is a source of great confusion between geological processes and impact-generated structures.

Our work shows some unexpected geophysical findings that are related to the tectonic properties and evolution of the Maâdna structure. The initial structural evolution of the Maâdna crater is mostly accessible from the geophysical data and magneto-structural data (paleomagnetic and AMS). The postemplacement tectonic plays a preponderant role in disturbing partially the initial paleomagnetic signal, such as the post-tilting reverse component. Despite the weakness of the AMS signal, there is no objective criterion allowing us to reject its postemplacement tectonic origin. Clearly, vertical movements have played a significant role for the formation of the main secondary folding of the strata. This could occur both in a diapiric system and in impact craters.

\section{Age of Emplacement}

According to Karpoff (1953), the Maâdna crater dates, at the earliest, from the latest Pliocene, owing to the fact that the continental Pliocene formation which commonly lies subhorizontally in the Sahara platform, appears locally folded just to the North of the crater. Lambert et al. (1980) suggest an age of formation of 0.5-3 Myr, arguing that it cannot be more than a few millions years old due to the weak erosion of the crater, notably the presence of a well-preserved "ejecta blanket."

As illustrated by our paleomagnetic and AMS data, the tectonic context leading to the emplacement could be attributed to the Upper Miocene. Consequently, this argument can provide convincing evidence to reject the window of ages suggested by Karpoff (1953) and Lambert et al. (1980). In term of cosmogenic nuclide production (e.g., ${ }^{36} \mathrm{Cl}$ measurements), our relative age determination of the excavation of the structure confirms as well a pre-Pliocene age (e.g., at least $3 \mathrm{Ma}$ ), based on the clear Pliocene infill of the crater.

In the hypothesis of the Maâdna crater being a remnant of a Tertiary diapiric formation, one could explain the freshness of the crater structure arguing for a "recent" dissolution of the central evaporatic material, 
generating a depression in place of the initial diapir central dome. Knowing that after the completion of dissolution, the depression would have been filled with wind-blown material, generating both the observed superficial magnetic high and the deeper gravimetric low.

\section{Origin of the Maâdna Structure}

The new set of magneto-structural and geophysical data collected in our study do not clearly support the previous interpretation of an impact origin for the Maâdna structure. The hydrographic network, as shown in Fig. 1, diverges around the crater. This may suggest that the morphology, that is, the crater, was already present before the development of the hydrographic network. Alternatively, this confirms quaquaversal strata of the Maâdna structure, dipping significantly outward in all directions away from a central point (e.g., dip values, Figs. 1 and 2). On the basis of field and laboratory investigations, we have deduced the presence of an extensive fracture network in the crater floor, including radial and concentric peripheral fault systems indicating postemplacement deformation (Figs. 3c and 3d). The Maâdna structure is one of the rare places where we can see the uppermost limestones of the M'Zab plateau (Fig. 1) upturned quite steeply (Figs. 1-3). This configuration is compatible with an impact origin of the crater, but also with a diapir from which its evaporitic core would have been largely dissolved. The presence of large blocks of limestone piled up on the rim of the crater may also be explained by both phenomena: impact ejecta or blocks transported by the extruded evaporite. However, it should be noted that no evaporitic rocks have been described in the area of the Maâdna structure although this does not necessarily exclude their occurrence at depth.

Shock-induced deformations and transformations in rocks and minerals are critical for the identification of an impact structure. During our investigations, we have not recognized any shatter cones, nor any shocked minerals, although macroscopic and microscopic brecciation and intense fracturation (see Figs. 3 and 4) was widely observed. However, it should be mentioned that in some cases, such as at the Upheaval Dome (Buchner and Kenkmann 2008) and Hummeln (Alwmark et al. 2015) impact structures, although they are confirmed impact structures, only extremely rare shocked quartz grains were observed after very careful investigation of dozens of thin sections. In addition to well-established macroscopic shock effects at Jebel Waqf as Suwwan in Jordan (by the occurrence of nice shatter cones), Schmieder et al. (2011) also reported shock-metamorphic microfeatures in the microcrystalline chert groundmass. Unfortunately, we did not found these typical shock features in our described and sampled flint inclusions. Contrary to their findings at Jebel Waqf as Suwwan, Buchner and Schmieder (2010) found only very sparsely shocked mineral fragments at Steinheim Basin impact crater (SW Germany), although with macroscopic evidence of impact. However, the apparent absence of features related to shock metamorphism in the Maâdna breccia samples does not allow us to definitely exclude an impact origin for the crater structure. We also point out that the "breccia" observed are quite suggestive of indurated colluvium rather than impact or tectonic breccias.

Such ambiguous evidence for impact is observed in a significant number of alleged impact structures because of the lack of convincing shock-metamorphic effects, such as Gilf Kebir crater in southwestern Egypt, or the Arkenu structures in Libya, Lake Isli and Tislit in Morocco, Kebira on the Libyan-Egyptian border, etc. As discussed above, besides impact cratering, there are similar discussions in the literature dealing with the formation mechanism of the enigmatic structures, including the Mousso (Buchner and Schmieder 2007) and Faya Basin (Schmieder and Buchner 2007, 2010) structures in Chad, the Jebel Hadid structure in Libya (Schmieder et al. 2009), or until recently the Uneged Uul structure in Mongolia (Schmieder et al. 2013).

Obviously, the crater cannot be the result of the erosion of an anticline or due to other tectonic processes such as a pull-apart basin linked to a strike-slip faulting (as the one at the North Sea Silverpit crater documented by Smith 2004). These hypotheses do not explain the regularity of the dip of strata around the crater while elsewhere in the M'Zab plateau they lay almost subhorizontally. They also cannot explain the presence of the limestone blocks and overturned strata or a deformation which displays centrifuged stresses (Fig. 3).

A volcanic explosion origin is also an unlikely hypothesis. The absence of magmatic rocks and the absence of strong deep-seated magnetic anomaly do not favor a volcanic origin. Moreover, volcanism is completely unknown in this region (Karpoff 1953; Magloire 1970).

Because of the vicinity of the Maâdna structure to the Hassi R'Mel gas condensate reservoir, we should also consider the possibility of the crater being the result of an explosion of trapped gas. However, most of the known gas (or oil) accumulations are in anticlines and such reservoir units are deeply buried in this region (Lyle 2006). No geological criteria for such a typical trap were seen in the Maâdna crater.

A dissolved diapir with inverted relief is thus a plausible alternative to the impact theory despite the nonexistence of salt or gypsum traces inside and outside of the structure. In term of cosmogenic nuclide 
production (e.g., ${ }^{36} \mathrm{Cl}$ measurements), the derived denudation rate is in the $25-30 \mathrm{~m} \mathrm{Myr}^{-1}$ range. Such a rate, mostly achieved by dissolution, is quite typical for carbonate plateaux around the Mediterranean Sea (Ryb et al. 2014). With the dissolution of $\sim 100 \mathrm{~m}$ of rocks since the formation of the structure, it is understandable that the primary structure of the rim breccia has been blurred. We may eventually attribute the strata disruption and megabreccia aspect as a dissolution collapse feature rather than a tectonic feature. Presence of low density material at depth below the crater supports the diapir hypothesis. In addition, using a very sensitive instrument (Foerster gradiometer), we spent significant time searching the supposed ejecta for magnetic material, but found nothing like iron shale or magnetic impact melt.

Finally, the confirmation of an impact origin for the Maâdna crater waits for unambiguous shock deformations in minerals (such as planar PDFs in quartz) or traces of extraterrestrial matter (such as siderophile-element anomalies; Koeberl 2002; French and Koeberl 2010) to be unequivocally documented.

\section{CONCLUSION}

This study underlines the efficiency of the applied multidisciplinary approach including field observations, geophysical surveys, AMS, paleomagnetism, and petrography, for studying putative impact structures. Our results substantially improve our knowledge of the structural emplacement of the Maâdna crater. From the modeling of the geophysical data, we are able to constrain the geometry of the source bodies inside the crater. Paleomagnetic and rock magnetic experiments combined with microscopic observations show that detrital hematite is the main magnetic carrier, occasionally associated with magnetite. A characteristic magnetization is inferred from a stable remanence with both normal and reverse directions carried by these two minerals, but it is considered as a postfolding chemical remagnetization. Nevertheless, this can help constrain the age window of formation of the Maâdna crater, during Upper Miocene to Lower Pliocene. In addition, our cosmogenic nuclide dating confirms this window of ages rather than those suggested by Karpoff (1953) or estimated by Lambert et al. (1980). The search for evidences of shock metamorphism was not successful. Therefore, all the obtained results do not appear sufficiently conclusive to either rule out or confirm the impact hypothesis, versus a dissolved diapir hypothesis, for the formation of the Maâdna crater. A definite answer on the origin of formation of the crater will need further investigations to be conducted, including drilling.
Acknowledgments-This research has been supported under the collaboration between the CRAAG (Bouzaréah, Algeria) and the CEREGE (Aix en Provence, France) research institutions. The practical assistance and logistical help from the regional division of Sonatrach and from the Willaya of Laghouat, its local communities (Hassi R'Mel and Hassi Dellaâ), is duly acknowledged as well as the contribution of the Algerian security services for ensuring safety during the field trip to Maâdna. We are very grateful to Birgit Woods, the account manager handling Education Licenses at Geosoft Europe, who offered us a Research Advanced License for a fixed period to process our geophysical data. We are grateful to M. Uehara and M. Floquet for their help with our petrographic observations and for the interesting discussions. J. P. Cogné is acknowledged for helping with the PaleoMac software processing. The ${ }^{36} \mathrm{Cl}$ measurements were performed at the ASTER AMS national facility (CEREGE, Aix en Provence) which is supported by the INSU/CNRS, the ANR through the "Projects thématiques d'excellence" program for the "Equipements d'excellence" ASTER-CEREGE action, IRD, and CEA. We also thank P. Lambert and D. Belhai for geological fruitful discussions. We appreciate the very constructive reviews by Martin Schmieder and an anonymous reviewer. Their comments have greatly improved the manuscript.

\section{Editorial Handling - Dr. Gordon Osinski}

\section{REFERENCES}

Alwmark C., Ferrière L., Holm-Alwmark S., Ormö J., Leroux H., and Sturkell E. 2015. Impact origin for the Hummeln structure (Sweden) and its link to the Ordovician disruption of the L chondrite parent body. Geology 43:279-282. doi:10.1130/G36429.1.

Askri H., Belmecheri A., Benrabah B., Boudjema A., Boumendjel K., Daoudi M., Drid M., Ghalem T., Docca A. M., Ghandriche H., Ghomari A., Guellati N., Khennous M., Lounici R., Naili H., Takherist D., and Terkmani M. 1995. Geology of Algeria. In Well Evaluation Conference, Algeria, edited by Beghoul M. S. Ghomari A. and Izem M. Bath, UK: Schlumberger. pp. 1-93.

Belhaï D., Merle O., Vincent P., Devouard B., and Afalfiz A. H. 2006. Etat des connaissances et mise au point sur les cratères météoritiques du Sahara algérien, des indicateurs de pièges à hydrocarbures? Bulletin du Service Géologique de 1'Algérie 17:95-112.

Besse J. and Courtillot V. 2002. Apparent and true polar wander and the geometry of the geomagnetic field over the last 200 Myr. Journal of Geophysical Research 107:2300. doi:10.1029/2000JB000050.

Bierman P. and Steig E. 1996. Estimating rates of denudation using cosmogenic isotope abundances in sediment. Earth Surface Processes and Landforms 21:125-139.

Blakely R. J. 1996. Potential theory in gravity and magnetic applications. New York: Cambridge University Press. 441 p. 
Buchner E. and Kenkmann T. 2008. Upheaval Dome, Utah, USA: Impact origin confirmed. Geology 36:227-230. doi: $10.1130 /$ G24287A.1.

Buchner E. and Schmieder M. 2007. Mousso structure: A deeply eroded, medium-sized, complex impact crater in northern Chad? Journal of African Earth Sciences 493:71-78.

Buchner E. and Schmieder M. 2010. Steinheim suevite-A first report of melt-bearing impactites from the Steinheim Basin (SW Germany). Meteoritics and Planetary Science 45:1093-1107.

Cisowski S. M. 1988. Paleomagnetism of Manson structure cores inconsistent with a K/T link (abstract). 19th Lunar and Planetary Science Conference. p. 188.

Cogné J. P. 2003. PaleoMac: A Macintosh ${ }^{\mathrm{TM}}$ application for treating paleomagnetic data and making plate reconstructions. Geochemistry Geophysics Geosystems 4:1007. doi:10.1029/2001GC000227.

Corner B., Reimold W. U., Brandt D., and Koeberl C. 1997. Morokweng impact structure, Northwest Province, South Africa: Geophysical imaging and some preliminary shock petrographic studies. Earth and Planetary Science Letters 146:351-364.

Currie K. L. and Larochelle A. 1969. A paleomagnetic study of volcanic rocks from Mistastin Lake, Labrador, Canada. Earth and Planetary Science Letters 6:309-315.

Deutsch A. and Scharer U. 1994. Dating terrestrial impact events. Meteoritics 29:301-322.

Domeier M., Van der Voo R., and Torsvik T. H. 2012. Paleomagnetism and Pangea: The road to reconciliation. Tectonophysics 514-517:14-43.

De Wall H., Bestmann M., and Ullemeyer K. 2000. Anisotropy of diamagnetic susceptibility in Tassos marble: A comparison between measured and modeled and modeled data. Journal of Structural Geology 22: 1761-1771.

Dunlop D. J., and Ozdemir O. 1997. Rock magnetism: Fundamentals and frontiers. Cambridge, UK: Cambridge University Press. p. 573.

Earth Impact Database. 2013. http://www.unb.ca/passc/ ImpactDatabase/ (accessed 20 January 2013).

Fifield L. K., Ophel T. R., Allan G. L., Bird J. R., and Davie R. F. 1990. Accelerator mass spectrometry at the Australian National University's 14UD accelerator. In Proceedings of the 5th International Conference on Accelerator Mass Spectrometry, edited by Yiou F. and Raisbeck G. M. Nuclear Instruments and Methods 52: 233-237.

Fisher R. A. 1953. Dispersion on a sphere. Proceedings of the Royal Society of London 217:295-305.

French B. M. 1998. Traces of catastrophe: A handbook of shock-metamorphic effects in terrestrial meteorite impact structures. LPI Contribution 954. Houston, Texas: Lunar and Planetary Institute. $120 \mathrm{p}$.

French B. M., and Koeberl C. 2010. The convincing identification of terrestrial meteorite impact structures: What works, what doesn't, and why. Earth-Science Reviews 98:123-170.

Gattacceca J., Lamali A., Rochette P., Boustie M., and Berthe L. 2007. The effects of explosive-driven shocks on the natural remanent magnetization and the magnetic properties of rocks. Physics of the Earth and Planetary Interiors 162:85-98.

Gilder S. and Le Goff M. 2005. Pressure dependence on the magnetic properties of titanomagnetite using the reversible susceptibility method. In Advances in high-pressure technology for geophysical applications, edited by Chen J. H., Wang Y. B., Duffy T. S., Shen G.Y., and Dobrzhinetskaya L. Amsterdam: Elsevier. pp. 315-335.

Gradstein F. M., Ogg J. G., Smith A. G., Agterberg F. P., Bleeker W., Cooper R. A., Davydov V., Gibbard P., Hinnov L. A., House M. R., Lourens L., Luterbacher H. P., McArthur J., Melchin M. J., Robb L. J., Shergold J., Villeuneuve M., Wardlaw B. R., Ali J., Brinkhuis H., Hilgen F. J., Hooker J., Howarth R. J., Knoll A. H., Laskar J., Monechi S., Powell J., Plumb K. A., Raffi L, Rohl U., Sanfilippoo A., Schmitz B., Shackleton N. J., Shields G. A., Strauss H., Van Dam J., Veizer J., Van Kolfschoten T. H., and Wilson D. A. 2004. Geological time scale, Cambridge, UK: Cambridge University Press.

Grieve R. A. F., and Pilkington M. 1996. The signature of terrestrial impacts. AGSO Journal of Australian Geology and Geophysics 14:399-420.

Halls H. C. 1975. Shock-induced remanent magnetisation in late Precambrian rocks from Lake Superior. Nature 255:692-695.

Halls H. C. 1978. The use of converging remagnetization circles in paleomagnetism. Physics of the Earth and Planetary Interiors 16:1-11.

Hamilton T. D., Borradaile G. J., and Lagroix F. 2004. Subfabric identification by standardization of AMS: An example of inferred neotectonic structures from Cyprus. Geological Society, London, Special Publications 238:527-540.

Hargraves R. B. and Perkins W. E. 1969. Investigations of the effect of shock on natural remanent magnetism. Journal of Geophysical Research 74:2576-2589.

Hart R. J., Andreoli M. A. G., Tredoux M., Moser D., Ashwal L. D., Eide E. A., Webb S. J., and Brandt D. 1997. Late Jurassic age for the Morokweng impact structure, southern Africa. Earth and Planetary Science Letters 147:25-35.

Henderson R. G., and Zietz I. 1948. Analysis of total magnetic-intensity anomalies produced by point and line sources. Geophysics 13:428-436.

Henkel H., Reimold U. W., and Koeberl C. 2002. Magnetic and gravity model of the Morokweng impact structure. Journal of Applied Geophysics 49:129-147.

Henry B., and Le Goff M. 1995. Application de l'extension bivariate de la statistique de Fisher aux données d'anisotropie de susceptibilité magnétique: Intégration des incertitudes de mesure sur l'orientation des directions principales. Comptes-rendus de l'Académie des Sciences de Paris 320:1037-1042.

Hext G. 1963. The estimation of second-order tensors, with related tests and designs. Biometrika 50:353-373.

Holt J. W. and Kirschvink J. L. 1995. The upper Olduvai geomagnetic field reversal from Death Valley, California: A fold test of transitional directions. Earth and Planetary Science Letters 133:475-491.

Jelinek V. 1978. Statistical processing of magnetic susceptibility measured in groups of specimens. Studia Geophysica Et Geodaetica 22:50-62.

Jelinek V. 1981. Characterization of the magnetic fabric of rocks. Tectonophysics 79:63-67.

Karpoff R. 1953. The meteorite crater of Talemzane in southern Algeria. Meteoritics 1:31-38.

Kirshvink J. L. 1980. The least-squares line and plane and the analysis of palaeomagnetic data. Geophysical Journal of the Royal Astronomical Society 62:699-718. 
Koeberl C. 1994. African meteorite impact craters: Characteristics and geological importance. Journal of African Sciences 18:263-295.

Koeberl C. 1997. Impact cratering: An overview of mineralogical and geochemical aspects, after: Koeberl C. Impact cratering: The mineralogical and geochemical evidence. In Proceedings, "The Ames Structure and Similar Features," edited by Johnson K. and Campbell J. Oklahoma Geological Survey Circular 100: 30-54.

Koeberl C. 2002. Mineralogical and geochemical aspects of impact craters. Mineralogical Magazine 66:745-768.

Lamali A., Gattacceca J., Rochette P., and Boustie M. 2007. Experimental modeling of impact effects on the magnetic susceptibility of geological materials. Publications of the Institute of Geophysics, Polish Academy of Sciences C-99:18.

Lamali A., Abtout A., Merabet N., Rochette P., Maouche S., Boukerbout H., Meziane E. H., and Ayache M. 2009. Magnetic signature of the Maâdna crater structure (Talemzane, Algeria). Proceedings of the 1st Arab Impact Cratering and Astrogeology Conference, Amman. pp. 47-49.

Lamali A., Merabet N., Henry B., Maouche S., GraineTazerout K., Mekkaoui M., and Ayache M. 2013. Polyphased geodynamical evolution of the Ougarta (Algeria) magmatic complexes evidenced by paleomagnetic and AMS studies. Tectonophysics 588:82-99. doi:10.1016/ j.tecto.2012.12.007.

Lamali A., Merabet N., Henry B., Maouche S., Hamoudi M., and Ayache M. 2014. Réaimantations énigmatiques des formations du Silurien et du Dévonien. Bulletin du Service Géologique National 25:181-199.

Lambert P., McHone J. F. Jr., Dietz R. S., and Houfani M. 1980. Impact and impact-like structures in Algeria. Part I. Four bowl-shaped depressions. Meteoritics 15:157-179.

Lambert P., McHone J. F. Jr., Dietz R. S., Briedj M., and Djender M. 1981. Impact and impact-like structures in Algeria. Part II, multi-ringed structures. Meteoritics 16:203-227.

Le Goff M, Henry B., and Daly L. 1992. Practical method for Drawing a VGP path. Physics of the Earth and Planetary Interiors 70:201-204.

Louzada K. L., Weiss B. P., Maloof A. C., Stewart S. T., Swanson-Hysell N. L., and Soule S. A. 2008. Paleomagnetism of Lonar impact crater India. Earth and Planetary Science Letters 275:308-319. doi:10.1016/ j.epsl.2008.08.025.

Louzada K. L., Stewart S. T., Weiss B. P., Gattacceca J., and Bezaeva N. S. 2010. Shock and static pressure demagnetization of pyrrhotite and implications for the Martian crust. Earth and Planetary Science Letters 290:90101. doi:10.1016/j.eps1.2009.12.006.

Lyle C. 2006. Report of Working Committee 1. TRIENNIUM 2003-2006. Exploration, Production and Treatment of Natural Gas. Upstream Committee (WOC1) of the International Gas Union.

Magloire P. R. 1970. Triassic gas field of Hassi er R'Mel, Algeria. In Geology of Giant Petroleum Fields. AAPG Memoir 14:489-501.

McHone J. F. Jr., and Greeley R. 1987. Talemzane: Algerian impact crater detected on SIR-A orbital imaging radar. Meteoritics 22:253-264.

McElhinny M. W. 1964. Statistical significance of the fold test in palaeomagnetism. Geophysical Journal of the Royal Astronomical Society 8:338-340.
McFadden P. L. 1990. A new fold test for paleomagnetic studies. Geophysical Journal International 103:163-169.

McFadden P. L. and McElhinny M. W. 1988. The combined analysis of remagnetization circles and direct observations in palaemagnetism. Earth and Planetary Science Letters 87:161-172.

McFadden P. L. and McElhinny M. W. 1990. Classification of the reversal test in palaeomagnetism. Geophysical Journal International 103:725-729.

Misra S., Arif Md, Basavaiah N., Srivastava P. K., and Dube A. 2010. Structural and anisotropy of magnetic susceptibility (AMS) evidence for oblique impact on terrestrial basalt flows: Lonar crater, India. Geological Society of America Bulletin 122:563-574.

Nishioka I., Funaki M., and Sekine T. 2007. Shock-induced anisotropy of magnetic susceptibility; impact experiment on basaltic andesite. Earth, Planets and Space 59:e45-e48.

Pesonen L. J., Marcos N., and Pipping F. 1992. Palaeomagnetism of the Lappajärvi impact structure, western Finland. Tectonophysics 216:123-142.

Peters L. J. 1949. The direct approach to magnetic interpretation and its practical application. Geophysics 14:290-320.

Pilkington M. and Grieve R. A. F. 1992. The geophysical signature of terrestrial impact craters. Reviews of Geophysics 30:161-181.

Pohl J. and Soffel H. 1971. Paleomagnetic age determination of the Rochechouart Impact Structure (France). Zeitschrift fur Geophysik 37:857-866.

Pohl J. and Soffel H. 1977. Palaeomagnetic and rock magnetic investigations of Tertiary volcanics in Northern Bavaria. Journal of Geophysics 42:459-474.

Quesnel Y., Gattacceca J., Osinski G., and Rochette P. 2013. Origin of the central magnetic anomaly at the Haughton impact structure, Canada. Earth and Planetary Science Letters 367:116-122.

Rasmussen R. and Pedersen L. B. 1979. End corrections in potential field modeling. Geophysical Prospecting 27:749760.

Reid A. B., Allsop J. M., Granser H., Millett A. J., and Somerton I. W. 1990. Magnetic interpretation in three dimensions using Euler deconvolution. Geophysics 55:80-91.

Reimold W. U. and Koeberl C. 2014. Impact structures in Africa: A review. Journal of African Earth Sciences 93:57175. doi:10.1016/j.jafrearsci.2014.01.008.

Robertson W. A. 1967. Manicouagan, Quebec, paleomagnetic results. Canadian Journal of Earth Sciences 4:641-649.

Rochette P. 1988. Inverse magnetic fabric in carbonate bearing rocks. Earth and Planetary Science Letters 90:229237.

Rochette P., Jackson M., and Aubourg C. 1992. Rock magnetism and the interpretation of the anisotropy of magnetic susceptibility. Reviews of Geophysics 30:209-226.

Rochette P., Fillion G., Ballou R., Brunet F., Ouladdiaf B., and Hood L. 2003. High pressure magnetic transition in pyrrhotite and impact demagnetization on Mars. Geophysical Research Letters 30. doi:10.1029/ 2003 GL017359.

Ryb U., Matmon A., Erel Y., Haviv I., and Benedetti L. 2014. Styles and rates of long-term denudation in carbonate terrains under Mediterranean to hyper-arid climatic gradient. Earth and Planetary Science Letters 406:142-152.

Sahoui R. 2009. Etude géologique et structurale du cratère météoritique du cratère de Maadna. Essai de modélisation 
analogique. Thèse Magister, FSTGAT, USTHB, Alger. 160 p.

Sailhac P. 1999. Analyse Multiéchelle et Inversion de Données Géophysiques en Guyane Française. PhD thesis, IPGP, Paris, France. 256 p.

Schimmelpfennig I., Benedetti L., Finkel R., Pik R., Blard P. H., Bourlès D., Burnard P., and Williams A. 2009. Sources of in-situ $36 \mathrm{Cl}$ in basaltic rocks. Implications for calibration of production rates. Quaternary Geochronology 4:441-461.

Schmidt P. W. and Williams G. E. 1991. Palaeomagnetic correlation of the Acraman impact structure and the Late Proterozoic Bunyeroo ejecta horizon, South Australia. Australian Journal of Earth Sciences 38:283-289.

Schmidt V., Hirt A. M., Leiss B., Burlini L., and Walter J. M. 2009. Quantitative correlation of texture and magnetic anisotropy of compacted calcite-muscovite aggregates. Journal of Structural Geology 31:1062-1073.

Schmieder M. and Buchner E. 2007. The Faya basin (N Chad, Africa)-A possible impact structure? Journal of African Earth Sciences 47:62-68.

Schmieder M. and Buchner E. 2010. The Faya Basin (N Chad) revisited-Structural insights from central peak morphology and potential Martian analogs (abstract). In Nördlinger Ries Crater Workshop, Nordlingen, June 2010, \#7012. LPI Contribution 1559. Houston, Texas: Lunar and Planetary Institute. p. 1.

Schmieder M., Buchner E., and Le Heron D. P. 2009. The Jebel Hadid structure (Al Kufrah Basin, SE Libya)-A possible impact structure and potential hydrocarbon trap? Marine and Petroleum Geology 26:310-318.

Schmieder M., Reimold W. U., Buchner E., Khirfan M., Salameh E., and Khoury H. 2011. Shock metamorphic microfeatures in chert from the Jebel Waqf as Suwwan impact structure, Jordan. Meteoritics \& Planetary Science 46:574-586.

Schmieder M., Seyfried H., and Ochir G. 2013. The circular Uneged Uul structure (East Gobi Basin, Mongolia)Geomorphic and structural evidence for meteorite impact into an unconsolidated coarse-clastic target? Journal of Asian Earth Sciences 64:58-76.

Sharma P., Kubik P. W., Fehn U., Gove H. E., Nishiizumi K., and Elmore D. 1990. Development of ${ }^{36} \mathrm{Cl}$ standards for AMS. Nuclear Instruments Methods in Physics Research Section B: Beam Interactions with Materials and Atoms 52:410-415. doi:10.1016/0168-583X (90)90447-3.

\section{SUPPORTING INFORMATION}

Additional supporting information may be found in the online version of this article:
Smith K. 2004. The North Sea Silverpit Crater: Impact structure or pull-apart basin? Journal of the Geological Society, London 161:593-602.

Szabó E. and Halls H. C. 2006. Deformation of the Sudbury structure: Paleomagnetic evidence from the Sudbury breccia. Precambrian Research 150:27-48.

Talwani M. and Heirtzler J. R. 1964. Computation of magnetic anomalies caused by twodimensional bodies of arbitrary shape. In Computers in the mineral industries, Part 1, edited by Parks G. A. Geological Sciences 9: 464-480.

Tarling D. H. and Hrouda F. 1993. The magnetic anisotropy of rocks. London: Chapman \& Hall. 217 p.

Thompson D. T. 1982. EULDPH: A new technique formaking computer-assisted depth estimates from magnetic data. Geophysics 47:31-37.

Tikoo M., Gattacceca J., Swanson-Hysell N. L., Weiss B. P., Suavet C., and Cournède C. 2015. Preservation and detectability of shock-induced magnetization. Journal of Geophysical Research, Planets 120. doi:10.1002/ 2015JE004840.3.

Ugalde H., Valenzuela M., and Milkereit B. 2007. An integrated geophysical and geological study of the Monturaqui impact crater, Chile. Meteoritics and Planetary Science 42:2153-2163.

Urrutia Fucugauchi J., Delgadillo-Peralta M., Pérez-Cruz L., and Velasco-Villarreal M. 2012. Heating-induced changes in the anisotropy of magnetic susceptibility of impact breccias, Chicxulub crater (Mexico). Studia Geophysica et Geodaetica 56:769-787.

Watson G. S. 1956. A test for randomness of directions. Monthly Notices of the Royal Astronomical Society. Geophysical Supplement 7:160-161.

Wilson R. L. and Everitt C. W. F. 1963. Thermal demagnetization of some carboniferous lavas for palaeomagnetic purposes. Geophysical Journal of the Royal Astronomical Society 8:149-164.

Won I. J. and Bevis M. 1987. Computing the gravitational and magnetic anomalies due to a polygon: Algorithms and Fortran subroutines. Geophysics 52:232-238.

Yokoyama E., Trindade R. I. F., Lana C., Souza Filho C. R., Baratoux D., Marangoni Y. R., and Tohver E. 2012. Magnetic fabric of Araguainha complex impact structure (Central Brazil): Implications for deformation mechanisms and central uplift formation. Earth and Planetary Science Letters 331-332:347-359.

Zijderveld J. D. A. 1967. AC demagnetization of rocks: Analysis of results. In Method in Paleomagnetism, edited by Collinson D. W., Creer K. M., and Runcorn S. K. Amsterdam: Elsevier. pp. 254-286.

Fig. S1: Maâdna impact structure (Talemzane, Algeria). a) 3-D modeling of Landsat image by Dr. Carlos Roberto de Souza Filho (see the Earth Impact Database). b) Panorama of the crater from field photographs. 